\title{
Nombrar las veintenas en los códices. Estrategias coloniales de reconfiguración gráfica del año entre los nahuas
}

\section{The Names of the Veintenas in the Colonial Codices; Strategies of Graphic Reconfiguration of the Nahua Calendar}

Artículo recibido el Io de agosto de 20I7; devuelto para revisión el I2 de octubre de 20I7; aceptado I6 de mayo de 20I8, http://dx.doi.org/IO.2220I/iie.I8703062e.20I8.II3.2653

Ana Díaz Universidad Nacional Autónoma de México-Instituto de Investigaciones Estéticas, anadiaz@unam.mx

Líneas de investigación

Lines of research

Publicaciones más relevantes
Códices del centro de México, calendarios nahuas, cosmologías coloniales del centro de México.

Codices of central Mexico, Nahua calendars, colonial cosmologies of central Mexico.

El maiz se sienta para platicar. Códices y formas de conocimiento nahua, más allá del mundo de los libros (México: Universidad Iberoamericana/Bonilla Artigas Editores, 2016); "Introducción”, en Cielos e inframundos; una revisión de las cosmologías mesoamericanas, coord. Ana Díaz (México: Instituto de Investigaciones Históricas/Fideicomiso Felipe Teixidor y Montserrat Alfau de Teixidor), 7-23; "Venus más allá de las tablas astronómicas. Una relectura de las láminas 53-54 del códice Borgia", Estudios de Cultura Náhuatl, núm. 48 (20I4): 89-I28; "La primera lámina del Códice Vaticano $A$ ¿Un modelo para justificar la topografía celestial de la antigüedad pagana indígena?", Anales del Instituto de Investigaciones Estéticas XXXI, núm. 95 (otoño de 2009): 5-44.

Resumen El presente estudio analiza el repertorio gráfico del año solar (xiwitl) utilizado por los grupos nahuas en los códices coloniales que explican el funcionamiento del calendario prehispánico mexicano. En el mismo se encuentran tres tipos de registros, de los cuales sólo uno aparece en todas las fuentes consultadas: una serie de signos que reportan los nombres de las veintenas. Este sistema de notación ha sido identificado por otros autores, quienes asumen dos posturas en torno a su origen y función - ya sea que los consideren un repertorio prehispánico, o una invención novohispana. Al hacer un seguimiento de las imágenes y conceptos presentes en las fuentes del siglo XVI, propongo 
que este repertorio hunde sus raíces en el pasado precolombino, pero que se reconfiguró al entrar en contacto con la cultura calendárica y cosmográfica del Viejo Continente. En este espacio presento una reconstrucción de este repertorio, al analizar las transformaciones y adaptaciones sufridas como resultado del contacto con los conceptos temporales y los paradigmas propios del calendario cristiano.

Palabras clave Calendario nahua; veintenas; escritura nahua; códices coloniales; año indígena.

Abstract This text analyzes the graphic repertoires used in colonial manuscripts that explain the function of the pre-Hispanic Mexican annual calendar (xiwitl). The study reveals the use of three figurative cycles, but only one of these repertoires appears in all the sources examined: a system of signs which gives the names of the veintenas. This glyphic assembly seems to have been in use from pre-Columbian times, however it needed to be resignified before being incorporated into colonial sources produced for non-indigenous readers. In this study I follow the transformation of the visual codes that permitted the reconfiguration of the xiwitl through contact with Christian cosmographies.

Keywords Nahua Calendar; veintenas and Nahua year; Nahua writing systems; Nahua colonial codices. 


\author{
ANA DÍAZ \\ UNIVERSIDAD NACIONAL AUTÓNOMA DE MÉXICO \\ INSTITUTO DE INVESTIGACIONES ESTÉTICAS
}

\title{
Nombrar las veintenas en los códices Estrategias coloniales de reconfiguración gráfica del año entre los nahuas
}

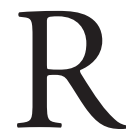
esulta primordial, antes de comenzar este texto, mencionar lo relativo a la ortografía empleada. Dado que uno de los objetivos de este trabajo consiste en ofrecer la reconstrucción de un repertorio escriturario en lengua náhuatl derivado de la reconstrucción epigráfica de una lengua precolombina, fue preciso utilizar un sistema ortográfico que permita una lectura fonéticamente transparente. Por este motivo se eligió utilizar la ortografía normalizada en los estudios de escritura jeroglífica maya, basada en las convenciones aceptadas por los miembros de la Academia de Lenguas Mayas de Guatemala. Esta ortografía contrasta con la utilizada en la literatura académica de tradición náhuatl, por lo que el lector habrá de familiarizarse con esta forma de representar las palabras y las fechas. El ejercicio de transliteración tomó en cuenta también la reconstrucción de la longitud vocálica, misma que se realizó tomando como referencia el diccionario de Frances Karttunen. ${ }^{\text {I Finalmen- }}$

I. Se han adoptado las siguientes convenciones ortográficas: se utiliza el alfabeto fonético estandarizado (a, e, i, o, ch, k, k $\left.{ }^{\mathrm{w}}, \mathrm{l}, \mathrm{m}, \mathrm{n}, \mathrm{p}, \mathrm{s}, \mathrm{t}, \mathrm{tl}, \mathrm{ts}, \mathrm{w}, \mathrm{x}, \mathrm{y}\right)$; la transcripción se realiza en negritas: los logogramas se escriben con letras mayúsculas y los silabogramas con minúsculas; las vocales largas se marcan con acento circunflejo (â, ê, $, \hat{l}, \hat{o})$; las aspiradas se marcan con "h"; las glotales, en caso de poder reconstruirse se marcan con saltillo ( ' ); la transliteración se reproduce en itálicas, los corchetes indican fonemas reconstruidos; las traducciones se indican entre comillas simples; 
te, la normalización del náhuatl aquí propuesta tomó en cuenta la de Andrea Rodríguez Figueroa y Leopoldo Valiñas, que resulta muy similar a la aceptada por la Academia de Lenguas Mayas de Guatemala. ${ }^{2}$ Esta ortografía tiene por objetivo distinguir la composición morfológica de las palabras sin necesidad de emplear el alfabeto fonético internacional. Cabe señalar que los nombres propios de lugares, personas y dioses se han respetado en la versión castellanizada, estandarizada, la normalización ortográfica sólo se utilizó para escribir el vocabulario calendárico nahua que es objeto de este estudio.

Ahora bien, este ensayo tiene por objetivo estudiar los repertorios gráficos utilizados por los grupos nahuas para registrar el ciclo anual (xiwitl), aunque el análisis se centra en la representación de las veintenas. El estudio toma como hilo conductor dos interrogantes: ¿cómo se representaba el ciclo de las veintenas en el Posclásico?, y ¿qué sucedió con este ciclo figurativo al entrar en contacto con el calendario y la cosmografía europea?

Iniciaré resumiendo el funcionamiento del cómputo del año solar de 365 días, denominado xiwitl en náhuatl. Éste se refiere en las fuentes coloniales como un ciclo dividido en 18 periodos de 20 días (sêsemilwitlapôwalli "cuenta de 20 en 20 ”), o veintenas. La suma de I8 veintenas abarca 360 días, por lo que se requiere un periodo extra de cinco días (nêmontemi) para alcanzar la cuenta total del año vago, o natural. Las veintenas se identificaron desde fechas muy tempranas como los meses del año mexicano (sus nombres aparecen en la tabla 2, véase anexo documental).

A lo largo de la investigación se identificaron tres repertorios gráficos utilizados para representar a las veintenas en las fuentes coloniales: un ciclo figurativo de dioses, un ciclo de festividades o rituales, y un repertorio de jeroglíficos que cumplen una función escrituraria. ${ }^{3} \mathrm{La}$ única fuente prehispánica que pude encontrar que presenta el registro de una veintena (fig. I) utiliza el tercer sistema

las palabras en náhuatl se indican en itálicas, a excepción de los nombres propios (de personajes y lugares), véase Frances Karttunen, An Analytical Dictionary of Nahuatl (Norman: University of Oklahoma, 1992).

2. Andrea Rodríguez Figueroa y Leopoldo Valińas, “¿Por qué normalizar la escritura del náhuatl clásico?”, mecanoscrito. El presente estudio sigue las convenciones propuestas por estos autores, excepto en el uso de "tl", que Rodríguez y Valiñas reconstruyen como " $\lambda$ ".

3. Este artículo presenta una versión actualizada y resumida de los resultados obtenidos en mi investigación doctoral en torno a la reconstrucción del registro gráfico prehispánico de las veintenas, véase Díaz, "Las formas del tiempo. Tradiciones cosmográficas en los documentos calendáricos indígenas del México central”, tesis doctoral (México: Universidad Nacional Autónoma de México: 20II), 232-385. 


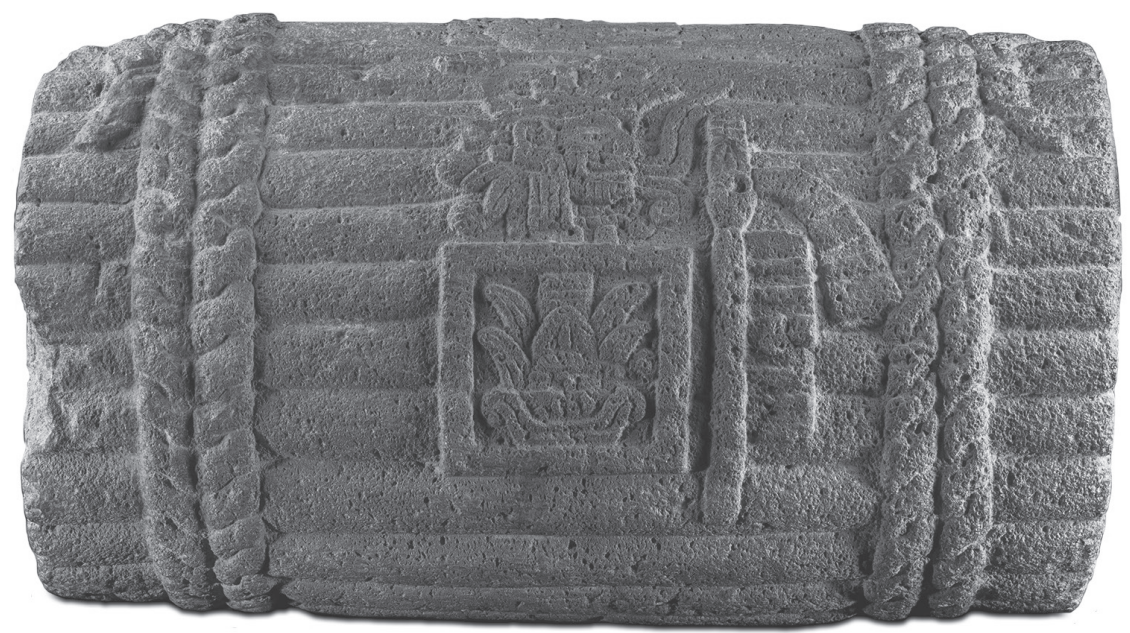

I. Escultura prehispánica que representa un xiwtlalpîli “ligadura de años”. El registro gráfico contiene el texto: [glifo no identificado], I-AKATL, PAN. [ỉ] I-âkatl, pânketsalistli, '[i] I-Caña, Levantamiento de banderas'. Sala Mexica. Museo Nacional de Antropología. Foto del Proyecto de Digitalización de las Colecciones Arqueológicas del Museo Nacional de Antropología. Secretaría de CulturaINAH-Méx. "Reproducción autorizada por el Instituto Nacional de Antropología e Historia".

de notación para escribir la fecha en que se llevó a cabo una ceremonia de Fuego Nuevo por un personaje no identificado ([?], I-AKATL, PAN; [?], I-âkatl, pânketsalistli, '[?] I-Caña, [en la veintena] Levantamiento de banderas').

El uso de este tercer repertorio de signos ha sido analizado por otros autores, quienes confrontan sus opiniones en torno a su origen. Brotherston y Nicholson consideran que su origen es prehispánico, ${ }^{4}$ mientras Kubler y Gibson proponen que se trata de una invención colonial construida como resultado de la introducción de la escritura alfabética latina. ${ }^{5}$ Además, Brown plantea la influencia del imaginario astrológico-zodiacal europeo en el desarrollo del repertorio nahua colonial. ${ }^{6} \mathrm{La}$ existencia de un objeto precolombino que inclu-

4. Gordon Brotherston, "Los textos calendáricos inscritos en el templo del Tepozteco", Estudios de Cultura Náhuatl, núm. 28 (1998): 77-97; Henry B. Nicholson, "Representing the Veintena Ceremonies in the Primeros Memoriales", en Representing Aztec Ritual, ed. Eloise Quiñones Keber (University Press of Colorado, 2002), 63-Io6.

5. George Kubler y Charles Gibson, "The Tovar Calendar", en Memoires of the Connecticut Academy of Arts \& Sciences, vol. XI (New Haven: Yale University Press, I95I), 39-4I.

6. Betty Brown, "European Influences in the Early Colonial Descriptions and Illustrations of the Mexican Monthly Calendar", tesis doctoral (Alburqueque: Universtiy of New Mexico, 1977). 
ye el registro escrito del nombre de una veintena permite corroborar el uso de este repertorio jeroglífico en época prehispánica. Sin embargo, coincido con los autores anteriores en que la incorporación de los ciclos figurativos calendáricos europeos modificó el registro y la concepción de las cuentas nahuas en el siglo Xvi. En este espacio me interesa analizar a detalle las transformaciones sufridas por este repertorio para identificar su origen, indagar la naturaleza de estas grafías - icónica o escrituraria—, ubicar su función en relación con otros sistemas de notación calendárica e imaginarios precolombinos; $y$, por último, estudiar de qué manera la inserción de la escritura y los formatos calendáricos europeos influyeron y guiaron la transformación del programa gráfico tradicional de las veintenas en los códices coloniales.

\section{El registro de las cuentas del tiempo en el centro de México}

\section{Características generales del registro de las cuentas del tiempo mesoamericano}

La notación calendárica está estrechamente ligada al desarrollo de la escritura, como se observa en la costa del Golfo, las tierras mayas, las zapotecas, la región del istmo y la vasta zona comprendida por las culturas de los valles centrales de México. ${ }^{7}$ El uso de las convenciones gráficas tradicionales para el registro temporal siguió vigente aún después del contacto con los españoles, ya que algunos documentos novohispanos presentan fechas escritas en el formato precolombino. ${ }^{8}$ El fenómeno es interesante porque implica una continuidad en la notación, y probablemente, la conceptualización misma del tiempo, aunque ello no conlleva una continuidad ahistórica y rígida.

Brevemente, la estructura básica del registro del tiempo propia de los grupos mesoamericanos puede resumirse en la presencia de dos elementos principales que se combinan en una cuenta: un numeral (I-I3) y un signo (I-XX). Juntos identifican a los días, fungiendo como su nombre y apellido. Este sistema

7. Véase Prudence M. Rice, "Time, Power and the Maya", Latin American Antiquity I9, núm. 3 (2008): 275-298; Carmack, Gasco y Gossen, "Introduction", en The Legacy of Mesoamerica, eds. Robert Carmack, Janine Gasco y Gary H. Gossen (Nueva Jersey: Pearson Prentice Hall, 2007), I-37.

8. Como el Códice Santa María Asunción, la Rueda Bobán, el Códice mendocino, la Tira de la Peregrinación, el Manuscrito Mexicanus 40, El Codex mexicanus, y la Matricula de Huexotzinco, entre otros. En estos documentos aparecen escritas fechas, topónimos, nombres personales y cuentas. 
de 260 unidades $(\mathrm{I} 3 \times 20=260)$ ha sido señalado entre los nahuas como tônalpôwalli, los zapotecos lo denominaban biyé, y actualmente se utiliza la palabra tzolk'in para referir a la cuenta maya - aunque este término se acuñó en el siglo xx. Por tanto, se puede hablar de un uso generalizado de esta cuenta en una amplia región, aunque no se conozca el nombre con el que el sistema fue designado por cada sociedad a lo largo de la historia precolombina. ${ }^{9}$

Esta cuenta estuvo en uso junto con otros sistemas de cómputo. Se tiene conocimiento de una cuenta de base vigesimal utilizada en las áreas istmeña y maya, que permitía contar la duración del año junto con otros ciclos temporales. ${ }^{10}$ La cuenta de 20 días formaba parte de un sistema vigesimal que contemplaba unidades de un día, llamado $K^{\prime}$ in en maya, que se sumaba formando múltiplos de 20: winal $(20$ días $=\mathrm{I} \times 20)$, tun $(360$ días $=20 \times 18), k^{\prime}$ atun $(7,200$ días $=360 \times 20)$ y $b^{\prime} a k t u n($ I 44,000 días $=7,200 \times 20)$. A este gran ciclo se le llama la Cuenta Larga. Dicha cuenta corre de manera paralela con la Rueda Calendárica, compuesta por el engranaje entre el ciclo de 260 días ( $t z o l k$ ' in) y el año de 365 días ( 18 veintenas +5 días extra). Cabe señalar que no existe evidencia arqueológica, ni histórica, del uso de la Rueda Calendárica, ni de la Cuenta Larga, entre los grupos del centro de México (nahuas, otomíes, mixtecos, entre otros).

\section{Las cuentas del tiempo nahua (siglos XV-XvI)}

Las fuentes coloniales mencionan que al momento del contacto con los espańoles los grupos nahuas del centro de México seguían tres tipos de cuentas

9. Las inscripciones istmeñas más tempranas con fecha escrita se han identificado como: el rollo cilíndrico de San Andrés (alrededor de 650 a.n.e.) que porta el nombre de 3 Ajaw (Pohl, Pope y von Nagy, "Olmec Origins of Mesoamerican Writing", Science, núm. 298 (2002): 1984-1986); la Estela 2 de Chiapa de Corzo (36 a.n.e.) y la Estela $\mathrm{C}$ de Tres Zapotes (32 a.n.e.). El texto maya más temprano de contexto arqueológico con fecha escrita de cuenta larga es la Estela 29 de Tikal, de 292 a.C. (Erik Velásquez, comunicación personal, 2016). También destacan el Monumento 3 de San José Mogote (siglo vi a.n.e.). Las estelas I2 y I3 de Monte Albán (siglo vi a.n.e.), el Monumento I3 de La Venta (ca. 400 a.n.e.). En Tlapacoya se encontró una cerámica datada por Niederberger entre el 900-800 a.n.e. donde aparece un motivo que puede tratarse de una fecha $\mathrm{I}-\dot{\mathrm{e}}$ ?, reproduciendo el modelo tradicional numeral/signo (Alfonso Lacadena, comunicación personal, 20Io).

Io. Para un estudio de los calendarios mexicanos véase: Alfonso Caso, Los calendarios prehispánicos (México: Universidad Nacional Autónoma de México-Instituto de Investigaciones Históricas, 1967). También se puede consultar: Prudence M. Rice, “Time, Power and the Maya”; Edmonson Munro, Sistemas calendáricos mesoamericanos (México: Universidad Nacional Autónoma de México, 1995). 
calendáricas: una de 260 días, otra de 365 días y un ciclo de I8, 980 días o de 52 ańos. ${ }^{\text {II }}$ A continuación presento un breve resumen del funcionamiento de estas cuentas para introducir la discusión que se seguirá en las siguientes líneas.

a) Tônalpôwalli

Consiste en una serie de 260 días obtenidos de la combinación de dos elementos: $\mathrm{I} 3$ numerales y 20 signos $(\mathrm{I} 3 \times 20=260)$. Se trata del registro calendárico más antiguo y utilizado, pues la lógica combinatoria de numeral-signo (I-I3 / I-XX) se puede rastrear desde el Preclásico hasta la época colonial, y en algunas comunidades hasta la época actual (véase el anexo documental, tabla I).

b) Xiwitl $y$ sêsemilwitlapôwalli

El sêsemilwitlapôwalli consta de 360 días formados por i8 veintenas $(\mathrm{I} 8 \times 20=360)$. Al concluir este ciclo se ańaden cinco días extra, los nêmontemi, para alcanzar los 365 días del año solar (xiwitl). Como el sêsemilwitlapôwalli tiene el mismo número de días que signos el tônalpôwalli (20), los grupos de 20 días o veintenas siempre inician con el mismo signo; pero, al llegar al día 360 y añadir cinco nêmontemi, se genera un desfase de cinco posiciones en la secuencia de signos-tônalli. Esta dinámica genera que cada año inicie con un día cuyo signo se encuentra a cinco posiciones de distancia respecto al día del año anterior $(20 / 5=4)$, generando cuatro familias de signos que se cono-

II. Francisco Cervantes de Salazar, Crónica de la Nueva España, vol. I. (Madrid: Atlas, 197I), I32, I42; Diego Durán, Historia de las Indias de Nueva españa e islas de Tierra Firme (México: Porrúa, 1967), 215-293; Jerónimo de Mendieta, Historia eclesiástica indiana (México: Consejo Nacional para la Cultura y las Artes, 2002), 2IO-2II; Toribio de Benavente Motolinía, Historia de los indios de la Nueva España (México: Porrúa, 1990), 25, 29-31; Bernardino de Sahagún, Historia general de las cosas de la Nueva España, t. 2 (México: Consejo Nacional para la Cultura y las Artes, 2002), 705-716, Códice Vaticano A, fol. I2r, en Ferdinand Anders, Maarten Jansen y Luis Reyes García, Religión, costumbres e historia de los antiguos mexicanos. Libro explicativo del llamado Códice Vaticano A (México: Fondo de Cultura Económica/ADEva, 1996), 95-I06; Códice Tudela, fols. 77r-84v y Códice magliabechiano, fols. I4r-27v, en Juan José Batalla Rosado, El Códice Tudela y el Grupo magliabechiano (Madrid: Ministerio de Educación, Cultura y Deportes-Agencia Española de Cooperación Internacional-Testimonio Compañía Editorial, 2002); Ferdinand Anders, Maarten Jansen y Luis Reyes García, El libro del Cihuacoatl; Homenaje del Fuego Nuevo, Libro explicativo del llamado Códice Borbónico (México: Fondo de Cultura Económica/Akademische Druck und Verlagsanstalt/Sociedad Estatal Quinto Centenario, I99I). 
cen como familias de portadores de año. Los nahuas de México-Tenochtitlan utilizaban la tercera familia de portadores (Kali III, Tồchtli VIII, Akatl XIII, Tekpatl XVIII).

Cada xiwitl constaba de 18 periodos de 20 días. Estos periodos aparecen referidos en las fuentes coloniales como veintenas, fiestas. Es preciso enfatizar la diferencia entre el sêsemilwitlapôwalli, que refiere a la cuenta de las I8 veintenas (360 días, o I $8 \times 20$ ), y el xiwitl, que alude al año de 365 días que se completa con los cinco nêmontemi. También es importante señalar que los nombres de las veintenas no cumplían con fines de notación calendárica, sólo aportan los nombres de las fiestas que se realizan cada 20 días. Es decir, a diferencia de la Rueda Calendárica maya y del calendario gregoriano, en el xiwitl no existe una cuenta de veintenas que utilice numerales. Así, para poder ubicar un día dentro de la veintena se utilizaba la fecha del tônalli, calculable con la posición de su signo. Sin embargo, como la cuenta del tônalli tiene sólo 260 días, en un año de 365 se repiten dos veces I05 días $(365-260=105)$. Por esta razón el problema de las correlaciones calendáricas ha hecho correr mucha tinta a los especialistas quienes buscan encontrar la clave para generar equivalencias entre el calendario gregoriano y las cuentas del centro de México, tanto nahuas como mixtecas (véase anexo documental, tabla 2)..$^{12}$

\section{c) Xiwpôwalli}

El xiwpôwalli o "la cuenta de xiwitl" es uno de los ciclos mas importantes del cómputo nahua. Abarca 52 años solares (xiwitl) y 73 ciclos de tônalpôwalli, quedan un total de I8, 980 días. La importancia de este periodo radica en que éste es el tiempo preciso que tardan en coincidir el primer día del xiwitl con el primer día del tônalpôwalli. Por eso cada 52 años se festejaba el Fuego Nuevo, que consiste en el ritual por excelencia de la renovación temporal en el centro de México. La representación gráfica de este periodo, el xiwtlalpîlli "ligadura de ańos" consiste en un manojo de varas atado con un nudo, o un puñado de hierba amarrado (véase fig. I). ${ }^{13}$

I2. Alfonso Caso ofrece un estudio que sigue siendo referencia obligatoria para los interesados en este tema. Caso, Los calendarios.

I3. Véase Marc Thouvenot, "Escrituras y lecturas del xiuhtlalpilli o ligadura de los años", Estudios de Cultura Náhuatl, núm. 34 (2003): 99-136. 
Las descripciones novohispanas. De la traducción a la reinvención conceptual

Como se ha mencionado, las veintenas recibían diferentes nombres en náhuatl, uno de ellos ilwitl, que se traduce como día y fiesta simultáneamente. ${ }^{14}$ Marc Thouvenot ofrece un estudio exhaustivo en el cual analiza con detalle los usos que recibía este término, mostrando la diversidad semántica de dicho concepto. ${ }^{15}$ Tlapôwalli, "la cuenta, cosa numerada o contada o cosa leída", ${ }^{16}$ es otro término con el que se designa a este ciclo en las fuentes, aunque su traducción tiene un sentido genérico por lo que su sentido para hablar de veintena, o trecena, sólo se reconstruye en el contexto. Esta palabra conforma la raíz de seesempoalapôwalli, "la cuenta de 20 en 20 " que se refiere al gran año de 360 días al que se suman los cinco nêmontemi para llegar al xiwitl. Otro término es mêtstli, que significa luna. El diccionario de la lengua náhuatl de Alonso de Molina ofrece las siguientes traducciones:

Entrada en lengua castellana: ${ }^{17}$

Mes parte dozena del año. metztli. Metztlapoualitztli.

Mes y medio. Cemetztli ypan tlaco. Centetl metztli ypan tlaco.

Entrada en lengua mexicana: ${ }^{18}$

Metztli. Luna, o pierna de hombre o de animal, o mes.

Metztli mayo. El mes de mayo. Et sic de alijs.

Cecemilhuitl. Cada día.

Esta referencia toma mayor sentido si se compara con la información ofrecida por Cristóbal del Castillo, quien distingue entre la cuenta de los meses europeos (lunas) y los ciclos indígenas, enfatizando que no son lo mismo. También informa que la asimilación entre ambos periodos se debe a los pintores de los libros (coloniales) quienes acompañaron por primera vez ambos registros:

I4. Alonso de Molina, Vocabulario en lengua castellana/mexicana y mexicana/castellana (México: Porrúa, 2004).

I5. Marc Thouvenot, "Iluhitl (día, parte diurna, veintena) y sus divisiones", Estudios de Cultura Náhuatl, núm. 49 (2015): 93-160.

I6. Molina, Vocabulario, fol. I32v.

17. Molina, Vocabulario, fol. $84 \mathrm{v}$.

I8. Molina, Vocabulario, fols. I5r, 55v. 
Y con las veintenas con las que celebraban fiesta era la manera [en que hacían] la cuenta de los meses. Porque no seguían la marcha de la luna: ni cuando se levanta por primera vez [...] Después todo lo emparejó, lo ordenó, lo dibujó el que lo escribió, el pintor de libros [entiéndase coloniales]. De modo que hizo acompañar los doce meses de un año, los hizo corresponder con las veintenas con las que festejaba la gente vieja. ${ }^{\text {I9 }}$

Ambas referencias apuntan a que el uso de mêtstli para designar a los meses se deriva de una práctica novohispana, pues en ninguna de las entradas del diccionario aparece asociada a veintenas nahuas y a la práctica europea de dividir el año en 12 meses lunares. Además, Del Castillo refiere abiertamente que esta práctica derivó de la necesidad de empalmar ambos calendarios. Por esta razón, no debe extrañar que el xiwitl (y sus i8 supuestos meses), sea uno de los periodos que aparece registrado con mayor frecuencia en los informes coloniales a pesar de que, como ya se ha mencionado, existían otras secuencias calendáricas que corrían de manera simultánea en el sistema mesoamericano. La asociación entre el calendario civil cristiano - basada en una secuencia de I2 meses que servían como la estructura sobre la cual se organizaban las actividades productivas - y el xiwitl, se mantuvo como el principal referente para explicar el funcionamiento del calendario indígena desde el siglo XVI.

La relevancia de esta distinción entre mêtstli e ilwitl radica en que confirma que la asociación con un ciclo astronómico se construyó como resultado del contacto con los conceptos temporales cristianos. Si nos remitimos a la traducción y el uso de la palabra ilwitl, encontramos que el énfasis está puesto en la fiesta y no en su asociación con eventos lunares. Aunque como se observa en el análisis de Thouvenot, este problema resulta mucho más complejo de lo que se expone en esta breve descripción, por lo que remito a su estudio. ${ }^{20}$

En el campo de la imagen, un ejemplo que permite identificar la transformación del repertorio antiguo de glifos de veintenas por nombres de meses aparece en las últimas páginas de la sección histórica del Códice Vaticano A, donde se registraron los eventos ocurridos con la llegada de Cortés a Tenochtitlan, se introduce la serie de 20 glifos para designar los pormenores del contacto (fig. 2). De este modo, la historia nahua cambia su estructura de anales, que

19. Cristóbal del Castillo, Historia de la venida de los mexicanos y de otros pueblos e Historia de la Conquista, trad. y estudio, Federico Navarrete (México: Consejo Nacional para la Cultura y las Artes, 200I), I6I-I62.

20. Thouvenot, "Iluhitl". 


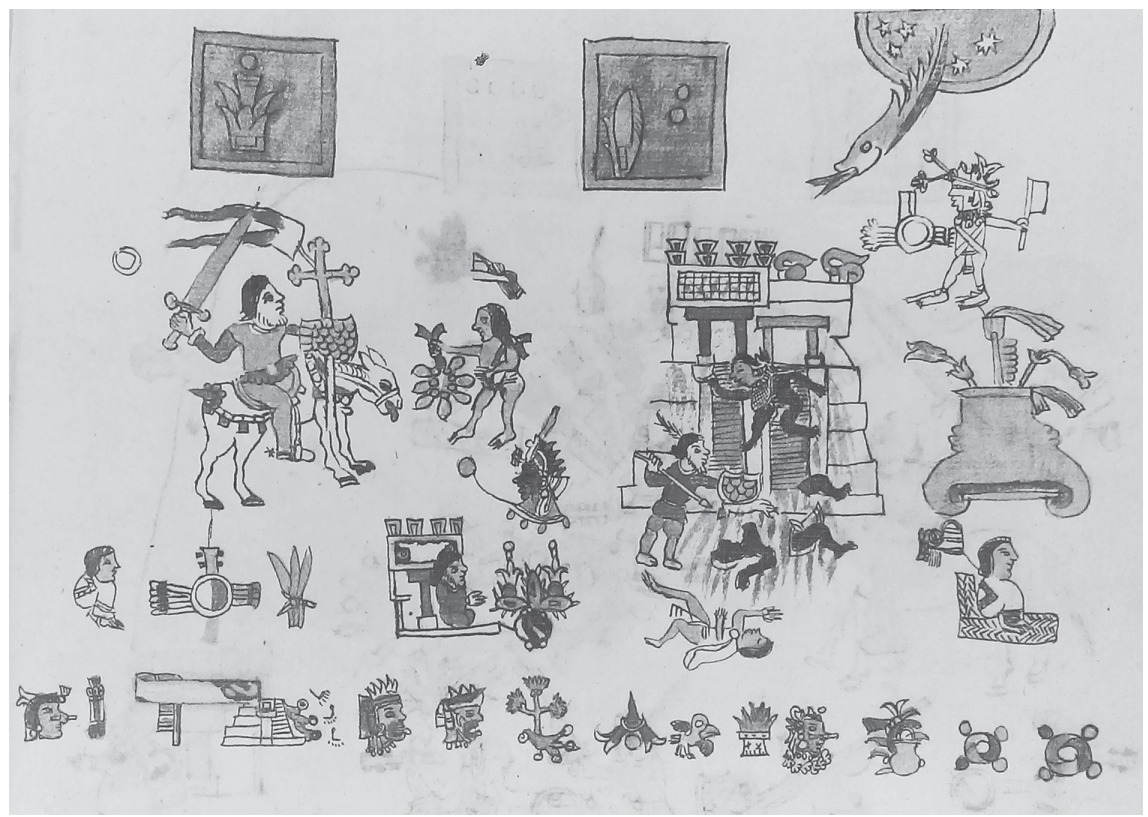

2. Códice Vaticano A, folio $87 \mathrm{r}$ (siglo XvI). Registro de un sêsemilwitlapôwali plasmado como un repertorio de meses que permiten datar los sucesos ocurridos en los años I-Aakatl y 2-Tekpatl en los anales del códice Vaticano A, tomado de Anders, Jansen y Reyes García, Religión, costumbres e historia de los antiguos mexicanos. Libro explicativo del llamado Códice Vaticano A (México: ADEVA/ Fondo de Cultura Económica, 1996).

hasta entonces había articulado el discurso, para introducir la cuenta mensual del tiempo después de la llegada de los españoles. En este caso los glifos de cada ilwitl funcionan como los nombres de los meses de los años I-Âkatl y 2-Tekpatl, durante los cuales sucedieron los eventos. En este ejemplar es posible identificar la adaptación de un registro prehispánico de nombres que se reconfigura como un sistema de datación mensual, siguiendo las convenciones de la narrativa lineal histórica presente en la literatura europea.

\section{El registro gráfico de las veintenas} y la creación del ciclo figurativo del año mexicano

Después de un análisis minucioso de los códices coloniales, elaborados con el fin de explicar el funcionamiento del calendario anual de los pueblos del 
centro de México ante el público ajeno a este universo cultural, fue posible identificar tres diferentes códigos visuales para representar a las veintenas: un ciclo de deidades, señalados como los patrones de cada veintena (ciclo figurativo de dioses) (véase anexo documental, tablas 3 y 4); un ciclo de fiestas que presenta momentos significativos dentro de las celebraciones de cada ilwitl (ciclo figurativo de fiestas) (véase anexo documental, tabla 4); una secuencia de glifos que designan a las veintenas (repertorio jeroglífico). Éstos, por lo general, aparecen en composiciones realizadas en formato de tabla o rueda calendárica, aunque también incorporados iconográficamente dentro de los repertorios arriba señalados, por lo que pueden pasar inadvertidos si no se conoce el repertorio (véase anexo documental, tablas 3 a 6 ).

Al hacer un cruce de datos se observa que los únicos elementos que se repiten en todos los repertorios son los glifos del último inciso. Y después de ampliar la muestra para incluir otras fuentes fue posible encontrar estos mismos elementos en códices de tributo (Fragmento Humboldt, Matrícula de tributos) y piezas arqueológicas (atado de años del Museo Nacional de Antropología). Incluso en materiales ajenos al área nahua, como la Piedra de Cuilapan, de origen mixteca. En la tabla 3 se muestran los resultados obtenidos del análisis de la muestra del estudio (véase anexo documental).

Antecedentes de los ciclos figurativos calendáricos anuales

Es importante notar que en la muestra de códices coloniales diseñados para que un lector ajeno al universo conceptual temporal nahua comprendiera el funcionamiento del "calendario mexicano", los tlakwîlôkeh configuraron dos tipos de programas: el xiwitl, ${ }^{21}$ con 365 días, o el sêsemilwitlapôwalli, ${ }^{22}$ que excluye la

21. Esto sucede en fuentes como el Códice Telleriano Remensis, la Rudea Boban, el Calendario Tovar, la Rueda 5 de Veytia, véase ed. Quiñones Keber, Codex Telleriano Remensis, facsímil (Austin: University of Texas Press, I995); Tovar, "Calendario", en Historia de la benida de los Yndios a poblar a Mexico delas partes remotas de Occidente (ca. 1582-1587), The John Carter Brown Library, Providence; Rueda Bobán (ca. I545-I546), The John Carter Brown Library, Providence; Mariano Veytia, Calendarios mexicanos (México: Museo Nacional de México, 1907).

22. Por ejemplo: Codex borbónico, facsímil (Graz, México: Akademische Druck und Verlagsanstalt/Fondo de Cultura Económica/Sociedad Estatal Quinto Centenario, I99I); Codex Vaticano A, facsímil (Graz, México: Akademische Druck und Verlagsanstalt/Fondo de Cultura Económica/ Sociedad Estatal Quinto Centenario, 1996); Códices del grupo Tudela-Magliabechiano, en Juan José Batalla Rosado, El Códice Tudela y el Grupo; Primeros memoriales, en Bernardino de Sahagún, Primeros memoriales, paleografía y traducción, Sullivan (Norman: University of Oklahoma Press, 
representación de los nêmontemi. Todos los programas responden a una misma coherencia interna, a la ejecución de un repertorio simétrico y congruente. Sin embargo, fuera de los códices pertenecientes a un mismo grupo - porque su producción está relacionada mediante copias, véase el anexo documental tabla 3-, no fue posible identificar un modelo original que les diera sustento a todos los repertorios. Es decir, no fue posible reconocer una unidad estructural que sí se puede observar en los registros coloniales del tônalpôwalli, mismos que además son consistentes con las imágenes que aparecen en los tônalâmatl prehispánicos. Sin embargo, las imágenes pintadas en libros coloniales permiten señalar, a grandes rasgos, dos repertorios iconográficos asociados a las veintenas: el ciclo de los dioses y el de las fiestas. Éstos se complementan con un repertorio gráfico de glifos, que se tratará en los siguientes apartados.

Para comprender la organización y funcionamiento de estos ciclos figurativos es preciso analizar la manera en que funcionaban los repertorios prehispánicos y cristianos vigentes para el siglo Xvi. El segundo caso resulta sencillo de cotejar dada la existencia de una amplia variedad de materiales escritos que muestran las transformaciones históricas de las concepciones calendáricas por medio de complejos programas figurativos presentes en la literatura cosmográfica. En contraste, la cultura visual precolombina asociada al registro de las veintenas no se ha podido rastrear, aunque algunos autores consideran que el Códice borbónico puede identificarse como el eslabón perdido que permite reconstruir el imaginario prehispánico mexicano. ${ }^{23} \mathrm{~A}$ continuación presen-

1997); Códice florentino, en Bernardino de Sahagún, Códice florentino, facsímil (México: Secretaría de Gobernación, 1979); Calendario Durán, en Códice Durán (México: Arrendadora Internacional, 1990); Rueda 4, en Mariano Veytia, Calendarios mexicanos.

23. El problema en torno a este códice inicia con la ubicación misma de su origen. El tema ha sido abordado por varios especialistas, quienes sostienen diferentes opiniones sobre su manufactura y temporalidad. Véase George Kubler y Charles Gibson, "The Tovar Calendar"; Jacqueline de Durand-Forest, "Códice borbónico y Códice Tonalamatl Aubin, semejanzas y diferencias a propósito de un caso particular: los nueve señores de la noche”, en Primer Coloquio de documentos pictográficos de tradición náhuatl, ed. Carlos Martínez Marín (México: Universidad Nacional Autónoma de México, 1989), 26I-278; Jacqueline de Durand-Forest, "Nuevas consideraciones sobre el simbolismo del Tonalamatl del Códice borbónico", en Segundo Simposio sobre códices y documentos de México, vol. I, eds. Salvador Rueda Smithers, Constanza Vega Sosa y Rodrigo Martínez Baracs (México: Instituto Nacional de Antropología e Historia-Consejo Nacional para la Cultura y las Artes, 1997); Ferdinand Anders, Maarten Jansen y Luis Reyes García, El libro del Cihuacoatl. Homenaje del Fuego Nuevo. Libro explicativo del llamado Códice borbónico (México: Sociedad Estatal Quinto Centenario/Fondo de Cultura Econónima/ADEVA, I99I); Juan José Batalla Rosado, "La perspectiva planigráfica indígena prehispánica y el Códice borbónico", Revista Española 
to las razones que me llevan a descartar este códice como fuente de referencia para reconstruir el repertorio calendárico anual.

\section{El calendario del Códice borbónico}

El problema inicia con la ubicación del origen del códice. El tema ha sido abordado por varios especialistas, quienes sostienen diferentes opiniones sobre su manufactura y temporalidad. Sin pretender exponer el tema de forma exhaustiva, el Códice borbónico presenta elementos que permiten identificar la influencia de la cultura visual europea en su manufactura. Al iniciar con la composición espacial de la sección dedicada a las veintenas, ${ }^{24}$ encontraremos que el eje compositivo se rige con los principios organizativos propios de la pintura y los grabados europeos, donde los personajes se distribuyen sobre el espacio abierto - en lugar de aparecer en secuencias acotadas entre franjas horizontales, como sucede en los códices mixtecos precolombinos, o en los materiales líticos toltecas y nahuas. En este sentido, la composición está muy cercana a una vista aérea o a una perspectiva espacial que organiza el espacio sobre el que se distribuyen los personajes (las plazas) de manera naturalista. Además, una de las principales características compositivas de esta sección consiste en la falta de uniformidad en el manejo del espacio, pues la extensión otorgada a cada veintena es desigual, al romper la simetría y generar un mayor énfasis en algunas de las series, una situación que no resulta compatible con el tipo de composiciones utilizadas por los pintores de los tônalâmatl, donde dentro de una misma sección se otorga la misma extensión y un arreglo muy similar a cada periodo que compone una serie. La falta de uniformidad no sólo se sustenta en la extensión otorgada a cada ciclo, sino en las estrategias compositivas de cada veintena. Por ejemplo, Xilômanalistli se representa con tres elementos exentos pero conectados: un personaje, un objeto y un glifo, generando una composición sintética que destaca la indicidad de los elementos; mientras en Ochpânistli se muestra una compleja secuencia narrativa que abarca dos láminas y presenta más de 20

de Antropología Americana, núm. 23 (1993): II3-134; Juan José Batalla Rosado, "Los tlacuiloque del Códice borbónico. Análisis iconográfico de los signos calendáricos", Estudios de Historia Social y Económica de América, núm. Io (1993): 9-24; Michael Graulich, "Elementos de las fiestas de las veintenas en las trecenas del Códice borbónico", en Códices y documentos sobre México, Segundo Simposio Internacional, vol. II, eds. Salvador Rueda Smithers, Constanza Vega Sosa y Rodrigo Martínez Baracs (México: Instituto Nacional de Antropología e Historia, 1997), 205-220.

24. Códice borbónico, 23-37. 
personajes en escena. En esta imagen se percibe la intención de representar un momento específico del ritual a detalle, por lo que se pueden diferenciar dos formas discursivas dentro de la misma sección del códice.

Aunque la composición de esta sección remite a códigos ajenos a la cultura visual nahua, los pintores incorporaron elementos de la tradición plástica nahua para expresar el contenido de las láminas. La intención por generar un nuevo repertorio a partir de la interacción de elementos provenientes de distintas tradiciones se observa al analizar las estrategias compositivas, que varían en cada veintena. Así, en Tề $k^{w}$ ilwitôntli el pintor utiliza las convenciones plásticas prehispánicas para representar la cancha del juego de pelota — que consiste en plasmar este espacio en una vista aérea - acompañada por los personajes, quienes se presentan en vista lateral. De este modo la imagen despliega dos planos simultáneos (vista superior y lateral), siguiendo la manera tradicional de desplegar el espacio delimitado por la cancha en el centro de México. Este recurso gráfico contrasta con el empleado en la fiesta de Xokotlwetsi, donde los personajes que rodean al palo erguido muestran con claridad una influencia de la perspectiva utilizada en los grabados europeos. Finalmente, es importante señalar que en esta sección del códice se utilizaron líneas negras verticales para separar los registros de cada veintena. Considero que este recurso compositivo es también ajeno a la plástica nahua. ${ }^{25}$

Pasemos ahora a un problema de contenido. La sección analizada ${ }^{26}$ presenta el ciclo festivo de las veintenas abarcando is láminas, donde se muestran I9 veintenas — pues la primera veintena se representa dos veces, al inicio y al final de la serie. Este acto implica que el tlak $k^{w} \hat{\imath} l o ̂$ incorporó una secuencia cíclica que abarca una cuenta que se sigue de manera ininterrumpida. Esta estrategia no aparece registrada en los tônalâmatl, a pesar de que la cuenta tônalli

25. El Códice Fejérváry-Mayer presenta una sección donde el espacio se configura a partir de líneas negras que contrastan con las convenciones gráficas del tônalâmatl, donde las líneas son rojas. Las páginas parecen ilustrar una práctica cercana al ritual de ofrendas contadas observada por Leonhard Schultze Jena en una comunidad tlapaneca. Éste es, junto con el Códice borbónico, el único caso en que se utiliza el color negro para delinear espacios. Sin embargo, las escenas que se delimitan en el Fejérváry-Mayer no corresponden a las del Borbónico. No existen elementos que permitan elaborar una hipótesis sobre la práctica de las "líneas negras" por tratarse de los únicos ejemplares, sin embargo, el hecho de que el ciclo de las veintenas aparezca organizado a partir de líneas rojas en los Primeros memoriales — en contraste con las negras del Códice borbónicopermite identificar una falta de unidad en el discurso plástico de las veintenas que parece responder a los ejercicios de producción de un nuevo repertorio gráfico para este ciclo.

26. Códice borbónico, 23-37. 
también se continúa ininterrumpidamente una vez que inicia. La selección de esta estrategia plástica permitió al pintor presentar una cuenta de veintenas que vinculan al año I-Conejo y el 2-Caña, que Anders, Jansen y Reyes García ubican en el año 1507. ${ }^{27}$ Aunque no es posible identificar con precisión el año que está representado, es posible apreciar la intención del tlak $k^{w} \hat{\imath} l \hat{\text { por mos- }}$ trar un periodo o espacio temporal específico, histórico, que podría ubicarse en el año I507, o 52 años antes o después. La razón por la que el ciclo de las veintenas inicia en Iskalli es desconocida, aunque si observamos las correlaciones que dan los cronistas entre el calendario juliano y el mexicano, notaremos que la mayoría considera que el año iniciaba en las veintenas $\mathrm{K}^{\mathrm{w}}$ awitlewa o Tlâkaxîpêwallistli (véase el anexo documental, tabla 2), que los autores ubican entre el $\mathrm{I}^{\mathrm{o}}$ de febrero y el 2 de marzo. Es decir, si el tlak $k^{w} \hat{\imath} l \hat{o}$ estuviera representando un calendario mensual tomando como referencia el año cristiano, iniciaría la cuenta en enero - en la última veintena del xiwitl anterior. Para no romper el orden del sesêmilwitlapôwalli, los autores de esta sección decidieron incorporar nuevamente la veintena $\mathrm{I}^{\mathrm{a}}$ para cerrar el ciclo. Es interesante observar que esta última veintena que conforma el ciclo se asocia con el año 3-Tekpatl, lo que genera un problema en la correlación porque el ciclo figurativo de I8 veintenas queda asociado al final del xiwitl I-Tôchtli, a la totalidad 2-Âkatl y al inicio de 3-Tekpatl. Aritméticamente la correlación es errónea, pues un ciclo de 19 veintenas (380 días) no concuerda con los tres años registrados. Sin embargo, la composición de la imagen subraya la intención por correlacionar el calendario cristiano y el xiwitl, como si fueran equivalentes. Así, la imagen muestra la intención del tlakwîlô por anclar el sêsemilwitlâpowalli al calendario cristiano, el cual se establece como el eje de la composición. La relación se explica de la siguiente manera: la primera veintena Iskalli corresponde a enero de I-Tôchtli (según el calendario Tovar va del I2 al 3I de enero); las i8 veintenas del centro corresponderían a los meses de enero-febrero a diciembre del año 2-Âkatl, y la última veintena de la cuenta (que implica volver a registrar a Iskalli), equivaldría al mes de enero del año 3-Tekpatl. Esta cuenta es confusa, pero la organización espacial y la relación de los componentes de las láminas permite mantener una coherencia general con el funcionamiento del calendario mensual-anual juliano. El compositor indígena siguió la misma estrategia del calendario de Juan de Tovar, quien ubica la veintena Iskalli en el mes de enero. De este modo, la configuración del repertorio en sí misma puede considerarse 
una evidencia de que el ciclo figurativo de este códice es posterior al contacto, y que busca una reconstrucción ideal de un calendario anual que toma como referencia el tiempo cristiano. ${ }^{28}$

El origen colonial del códice no es motivo suficiente para dudar de su autenticidad como fuente de reconstrucción, pero el principal problema para aceptar que en él se representa un calendario tradicional de veintenas radica en que no se conoce un registro similar en ninguna otra fuente ni prehispánica ni colonial que presente un código visual semejante. En otro estudio he cuestionado el recurso común de apelar a la destrucción de códices para justificar la ausencia de un repertorio visual que debería estar presente, directa o indirectamente, en otros artefactos. ${ }^{29}$

\section{El calendario cristiano del siglo xvI}

En este punto, cabe voltear a ver al Viejo Continente para observar cuál era el imaginario asociado a los meses del calendario cristiano. En su estudio de calendarios medievales, Castiñeiras identifica la siguiente dinámica: el formato más reproducido y fácilmente reconocible para todos los feligreses del siglo XVI consistía en el registro de los I2 momentos del año distribuidos en faenas agrícolas (siembra y cosecha de trigo y uva) y celebraciones (como la matanza del cerdo y la fiesta de año nuevo)..$^{30} \mathrm{El}$ año era así considerado por los cristianos como un ciclo de festividades relacionadas con la producción agropecuaria y celebraciones asociadas a fechas precisas del año; fiestas fijas ancladas al devenir astronómico-estacional. ${ }^{3 \mathrm{I}}$ El segundo repertorio vigente en la memoria de

28. Este tema y otros asuntos relacionados a la reconfiguración del imaginario calendárico nahua se trata en Díaz, El cuerpo del tiempo. Códices, cosmología y tradiciones cronográficas del centro de México, mecanoscrito.

29. Ana Díaz, "La primera lámina del Códice Vaticano $A_{¿}$ Un modelo para justificar la topografía celestial de la antigüedad pagana indígena?", Anales del Instituto de Investigaciones Estéticas XXXI, 95 (2009): 5-44.

30. Manuel Castiñeiras, El calendario medieval hispano. Textos e imágenes (siglos XII a XIV) (Salamanca: Junta de Castilla y León-Consejo de Educación y Cultura, 1996).

31. El énfasis en el carácter agrícola del año aparece en obras como: Johanna Broda, "Calendarios, cosmovisión y observación de la naturaleza”, en Temas mesoamericanos, coords. Sonia Lombardo y Enrique Nalda (México: Instituto Nacional de Antropología e Historia-Consejo Nacional para la Cultura y las Artes, 1996), I45-I65; Johanna Broda, "Ciclos agrícolas en el culto: un problema de la correlación del calendario mexica”, en Calendars in Mesoamerica and Peru Native Computations of Time; eds. Aveni y Brotherston (Oxford: Bar, 1983), I45-165; Michel Graulich, Ritos aztecas. Las fiestas de las veintenas (México: Instituto Nacional Indigenista, 1999). 
los religiosos eran los calendarios que mostraban el culto de los antiguos pueblos - como los romanos y griegos_-, compuestos por ruedas o tablas donde a cada mes le correspondía una deidad regente, generalmente asociada con un ciclo astronómico basado en los siete planetas. ${ }^{32}$ En este tipo de repertorios se puede ubicar el ciclo del zodiaco. Estas recopilaciones eran accesibles en manuscritos de los monasterios, por lo que no contaban con tanta difusión entre los feligreses como el de las fiestas y faenas.

Considero que los códices coloniales citados en este apartado, los cuales se confeccionaron para llegar a lectores no indígenas, podrían estar incorporando elementos de estos dos repertorios cronográficos producidos del otro lado del Atlántico. La adopción de estas convenciones gráficas permitirían darle a esos "tiempos otros", una forma coherente con los paradigmas teológicos y cosmográficos cristianos, rastreando los datos que fueran adaptables a la estructura conceptual cronológica del tiempo universal y verdadero. Esa estrategia permitiría explicitar el funcionamiento del xiwitl para asociarlo con el año solar, estacional, civil y litúrgico, que regula las fiestas fijas cristianas. Este fenómeno toma sentido si consideramos que los destinatarios de estos documentos eran autoridades novohispanas. ${ }^{33}$

En contraste con estos códices, en aquellas fuentes que parecen haber sido confeccionadas para usuarios entendidos en la tradición indígena, nos encontramos con otro escenario. En ellas aparecen solamente los glifos del ilwitl. Esto sucede en el fragmento Humboldt i y en la Matrícula de tributos, códices administrativos donde se muestra que la recolección de tributos se realizaba en las veintenas Tlâkaxîpêwallistli; Etsalk ${ }^{w}$ allistli, Ochpânistli y Pânketsalistli, ubicadas a 80 días de distancia. El registro de glifos de ilwitl también aparece en un monumento lítico prehispánico, donde se refiere que en el año I-Tôchtli, en la veintena de Pânketsalistli, se realizó una ceremonia de atado de años

32. Motolinía es uno de los autores que relacionan los ciclos astronómico-astrológicos antiguos creados en el Viejo y el Nuevo Mundo, posteriormente estudiosos como Boturini continuaron con este modelo para explicar el funcionamiento del calendario nahua. Véase Toribio de Benavente, Motolinía, Memoriales, ed. e introd. Joe Dyer (México: El Colegio de México, 1996), I60-162; Lorenzo Boturini, Idea de una historia general de la América septentrional (Madrid: Juan de Zúniga, 1746), 37-44.

33. George Kubler y Charles Gibson, "The Tovar Calendar"; Brown, European Influences in Early Colonial; Elizabeth Boone, The Codex Magliabechiano and the Lost Prototype of the Magliabechiano Group, facsímil, 2 vols. (Berkeley: University of California Press, 1983); Ana Díaz, "Tlapohualli; la cuenta de las cosas. Reflexiones en torno a la reconstrucción de los calendarios nahuas", Estudios de Cultura Nábuatl, núm. 46 (2013): 159-197. 
(véase la figura I). Esta referencia resulta extraordinaria, pues generalmente los monumentos antiguos registran el nombre del año y del día en que ocurrió el evento en formato numeral-signo; es decir, dan su ubicación en el xiwpôwalli y tônalpôwalli. Sin embargo, el grabador de esta pieza enfatizó la celebración del ilwitl porque este dato resultaba importante en el contexto de la celebración del Fuego Nuevo. Este tipo de fechamiento (veintena-año) también aparece en la piedra de Cuilapan, un monumento colonial mixteco.

\section{El repertorio glífico del sêsemilwitlapôwalli}

$\mathrm{Al}$ analizar los documentos que conforman la muestra de este estudio se confirmó que los compuestos glíficos con que se registran las veintenas estaban presentes en todos los ejemplares. Si se toma en cuenta que los documentos provienen de diferentes localidades y que se elaboraron en distintos momentos, el hecho de que los glifos aparezcan constantemente implica que existe una continuidad histórica ligada a su registro, como lo señaló Nicholson. ${ }^{34}$ Así, la base sobre la que se sustenta la identificación del repertorio como una práctica indígena responde a lo que se ha identificado como una tradición notacional temporal mesoamericana. Una costumbre que implica el cómputo por medio de un corpus de signos; aunque en este caso estén ausentes los numerales. Por esta razón su función sería meramente designativa: sólo son nombres propios de ciclos, que no permiten seguir una cuenta detallada de días como el tônalpôwalli.

Es preciso aclarar que aunque todos los documentos que reproducen o ilustran escenas de las veintenas presentan glifos asociados, no todos utilizan el mismo repertorio de signos (véase el anexo documental, tablas 3 y 6). Es decir, no parece existir una sistematización, o por lo menos no es tan evidente como sucede con los 20 signos del tônalpôwalli.

La aparente falta de sistematización del repertorio de compuestos glíficos puede responder a varios factores. Como se observa en las tablas 2 a 6 , no existía un repertorio oficial universal para representar a las veintenas. Esto se debe a que, como han señalado otros autores, se ha observado que el sistema de veintenas presenta variaciones regionales, que no permiten hablar de una unidad en la nomenclatura. ${ }^{35}$ Esta situación hace posible identificar la naturaleza del repertorio glífico, que como se ha señalado es de carácter designativo; es decir,

34. Nicholson, "Representing the Veintena".

35. Caso, Los calendarios. 
se trata de nombres de periodos que en una gran mayoría de los casos sigue las normas de registro escriturario jeroglífico nahua. Esto indicaría que la naturaleza de los signos es de orden escrituraria y no icónica. Aunque es posible observar que los textos glíficos prehispánicos se incorporaron de manera icónica con el paso del tiempo en los códices coloniales, convirtiéndose en imágenes nuevas que remiten a conceptos y experiencias novedosas.

La naturaleza de los glifos de las veintenas, ¿prehispánica o colonial?

Al observar la forma que despliegan los glifos de este repertorio es posible identificar su origen dentro de la tradición plástica precolombina, aunque no existe consenso sobre el momento de su creación. Gordon Brotherston propone que los glifos de las veintenas tienen un origen prehispánico. ${ }^{36}$ Aunque coincido con este argumento, no considero que la muestra que toman como base para la identificación, los glifos del cerro del Tepozteco propuestos por Seler, sean una cuenta de sêsemilwitlapôwalli. Otro partidario del origen prehispánico de la cuenta, Henry B. Nicholson, menciona que existen elementos suficientes para aceptar que estas representaciones pueden insertarse perfectamente dentro de la tradición indígena. Uno de sus argumentos es el uso del mismo repertorio de signos en documentos producidos en regiones distantes: la meseta central de México, Guerrero y Oaxaca. ${ }^{37}$

Contrarios a esta posición, Kubler, Gibson y Brown sostienen que el repertorio glífico surgió durante la colonia como un intento de los tlak $k^{w} \hat{l} l \hat{k} k h$ nahuas por inventar un sistema fonético basado en grafías nativas para imitar la escritura alfabética europea. ${ }^{38}$ Sin embargo, este acto implica un proceso inverso al natural, pues cuando uno aprende un nuevo idioma comienza utilizando su propio sistema escriturario para registrar las nuevas palabras, y de manera simultánea aprende a utilizar los signos escriturarios asociados a la segunda lengua. El aprendiz sabe que cuando domine el nuevo idioma éste será registrado con sus propias grafías, desplazando los caracteres y la sintaxis del código nativo - véase lo que sucedió con los catecismos testerianos, que no pertenecen a ninguna de las tradiciones icónico-escriturarias. Por tanto, inventar un sistema híbrido de grafía, ajeno a ambas lenguas, es un intento vano

36. Brotherston, "Los textos calendáricos inscritos".

37. Nicholson, "Representing the Veintena", 96-ıоo.

38. Kubler y Gibson, "The Tovar Calendar"; Brown, European Influences in Early Colonial. 
porque implica un doble esfuerzo: mientras se aprende el nuevo idioma y sus grafías, se inventa un nuevo sistema gráfico ecléctico, incompatible con ambas tradiciones, a sabiendas de que éste será finalmente desechado cuando se haya aprendido la nueva legua y dominado su escritura. Los nahuas sabían que la escritura latina terminaría desplazando los sistemas gráficos autóctonos, por lo menos en ciertos espacios, y aprendieron a usar el alfabeto. No había razón para inventar un alfabeto-glífico operante para un solo usuario, en lugar de aprender el nuevo sistema.

Aunque esta explicación sobre la dinámica de aprendizaje de una lengua es coherente, en este estudio se retoma el argumento de Nicholson para replantear el origen prehispánico de este repertorio de signos. Como evidencia presento el análisis de una pieza mexica prehispánica que incluye uno de los signos de las veintenas en un monumento conmemorativo que permite corroborar su función al integrarlo en contexto (fig.I); y el hecho de que los signos de las veintenas encontradas en distintos documentos analizados siguen las características de la escritura nahua logofonética que también está presente en topónimos y nombres personales. Es importante señalar que aunque los códices de la muestra son coloniales - pues no han sobrevivido códices prehispánicos nahuas que reporten este ciclo-, los tlahk ${ }^{w}$ ilohke siguieron las disposiciones de una tradición escrituraria perfectamente establecida, e incluso, diferenciada regionalmente en las escuelas tetzcocana y tenochca-tlatelolca. ${ }^{39}$

Si bien el contacto con las culturas del Viejo Continente implicó la introducción de nuevos referentes conceptuales a la cosmovisión indígena, afectando también su concepción calendárica, ${ }^{4}{ }^{\circ}$ el uso de un repertorio mensual similar a la serie de signos registrada en los códices novohispanos no tiene referente en el contexto europeo. Brown comenta que estos glifos pueden reconocerse como una reinterpretación del zodiaco a los ojos indígenas. ${ }^{4 \mathrm{I}} \mathrm{Sin}$ embargo, estas formas están más cercanas a los conjuntos glíficos utilizados en el Posclásico para registrar topónimos y antropónimos, que a cualquier tipo de referente astronómico.

39. Alfonso Lacadena, "Regional Scribal Traditions: Methodological Implications for the Decipherment of Nahuatl Writing", The PARI Journal VIII, 4 (primavera 2008): I-23.

40. Victoria Bricker y Helga-María Miram, "Relating Time to Space; the Maya Calendar Compasses", en eds. Martha J. Macri y Jan McHargue, Palenque Round Table, vol. X (San Francisco: Precolumbian Art Research Institute, 1996), 393-402 y Betty Brown, European Influences in Early Colonial.

4I. Betty Brown, European Influences in Early Colonial, 276. 
Propuesta de lectura del repertorio glífico del sêsemilwitlapôwalli

En este apartado se presenta la reconstrucción de los nombres de las veintenas utilizados en distintas fuentes coloniales tomando como referencia el repertorio jeroglífico del sêsemilwitlapôwalli. ${ }^{42}$ Para iniciar la exposición, recordemos un aspecto señalado por Brown en su análisis del repertorio de glifos empleados para representar a las veintenas. La autora observó que éstos no presentan una lógica que permita acceder a los contenidos mediante una interpretación iconográfica, o por lo menos no en todos los casos. Efectivamente, la construcción de los glifos responde a una serie de criterios de composición que no apuntan a la presencia de un repertorio iconográfico, sino una escritura logosilábica que reproduce los nombres de las veintenas. Estas características consisten en el uso de un repertorio de signos compuesto por logogramas y fonogramas; el uso de logogramas en rebus por el valor de lectura y no por su significado principal; el uso opcional de fonogramas como complemento fonético de logogramas; la estructura del silabario fonético es de tipo v, CV y presenta abreviaturas como síncope, suspensión y la combinación de ambas, tiende a la disposición de los signos en bloques a manera de emblemas; la especialización en la temática. Es decir, los glifos se utilizan en contextos específicos: topónimos,

42. La selección de la terminología se basó en el análisis de los códices Borbónico, Tudela, Maglabechiano, Telleriano Remensis, Vaticano A, y Memoriales de Motolinía, Rueda Bobán, Primeros memoriales, el Códice florentino, y en el Calendario de Juan de Tovar, así como en los calendarios de Veytia, arriba citados. También en la Historia de las Indias de Nueva España e Islas de Tierra Firme (México: Porrúa, 1967) de Diego Durán, en la Historia eclesiástica indiana. Cantares mexicanos (s.f.), de Mendieta (ms. I628. [s.p.i.]. Biblioteca Nacional de México); La Matrícula de tributos (véase Arqueología Mexicana, edición especial, núm. I4, Serie de Códices [2003]); el Codex Mendoza, comentarios de Francis Berdan y Patricia Anawalt, 4 vols. (Berkeley: University of California Press, 1992); el Codex en Cruz, comentarios de Charles E. Dibble, 2 vols. (Salt Lake City: University of Utah Press, 198I); la "Tributación en la provincia de Tlapa, Códices Azoyú 2 y Humboldt Fragmento I", de Constanza Vega Sosa, en Códices y documentos sobre México. Primer Simposio (México: Instituto Nacional de Antropología e Historia, I994), I6I-I7I. También se consultaron las veintenas registradas por Serna en Jacinto de la Serna, Pedro de Ponce y Pedro de Feria, Tratado de las idolatrias, supersticiones, dioses, ritos, hechicerias y otras costumbres gentilicia, de las razas aborígenes de México, notas y comentarios de Francisco del Paso y Troncoso (México: Ediciones Fuente Cultural, 1953). Asimismo se tomó en cuenta la información de Cristóbal del Castillo, Historia de la venida de los mexicanos y Alfonso Caso, Los calendarios. Este análisis se profundiza en: Ana Díaz, "Las formas del tiempo. Tradiciones cosmográficas en los calendarios indígenas del México central”. 
antropónimos-teónimos y en contextos calendárico y aritmético. ${ }^{43}$ De modo que los textos registran sólo nombres de personajes, lugares, o ciclos temporales. Estos criterios se pueden identificar en los textos nahuas escritos antes del contacto, como se observa en los materiales arqueológicos (por ejemplo, la pieza reproducida en la fig. I).

La reconstrucción de los nombres de las veintenas fue sencilla, pues requirió atender los criterios de la teoría de la escritura, cuya metodología ha sido aplicada en el área maya. Como se observa en diversos textos escritos en caracteres jeroglíficos nahuas en otras fuentes, los nombres reconstruidos presentan abreviaturas, y siguen una composición emblemática, cuyos orígenes se pueden rastrear en los textos del Clásico y el Epiclásico (Teotihuacan, Xochicalco y Cacaxtla). En la tabla 6 (en el anexo documental) se muestran los nombres de las veintenas que pudieron reconstruirse y las fuentes donde se encontraron sus registros, y en la figura 3 se muestran algunos ejemplos de los textos. Así, en la figura 3a se observa el nombre de la veintena KwAW-a, $k^{w}$ aw [itlew] a, K ${ }^{\mathrm{w}}$ awitlewa, "se levanta/asienta el árbol". ${ }^{44} \mathrm{La}$ figura 3 b reproduce el nombre [WeI] TO-so wei-tôsostli, Weitôsostli "gran vigilia". ${ }^{55}$ En la figura $3 \mathrm{c}$ aparece el nombre

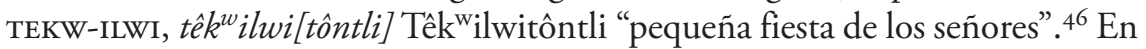
la $3 \mathrm{~d}$ se muestra la veintena TEPE, Tepêilwitl, Tepêilwitl "fiesta de los cerros". ${ }^{47}$ Finalmente, las figuras ze y $3 \mathrm{f}$ reproducen los nombres Teôtleko "sube el teôtl", y etsalkw allistli, Etsalkwallistli "guiso de frijoles con maíz [llamado etsalli]". La particularidad de estas representaciones consiste en que en apariencia se trata del mismo elemento gráfico, pero al analizar las construcciones es posible observar que el tlak $k^{w} \hat{\imath} l o ̂$ del Códice borbónico (fig. 3e) está escribiendo el logograma ETSA/ESA esa[lk $k^{w}$ allistli], correspondiente a la sexta veintena, que se identifica por los frijoles y granos de maíz pintados dentro del recipiente con asas. En contraste, el compositor de la Rueda Bobán (fig. 3f), quien sigue las convenciones de la escuela tetzcocana, utiliza la composición más marcadamente fonética: te-e-E-ko (piedra-frijol-viento[puntitos que rodean los frijoles]-olla) para escribir el nombre Teôtleko, la ${ }_{1} 2^{\circ}$ veintena. Es importante notar que en

43. Alfonso Lacadena, "Regional Scribal Traditions", I-23. Remito al lector a consultar esta obra para comprender el sentido que se da a los recursos de registro gráfico escriturario.

44. Códice Vaticano A, fol. 87r. El nombre también se registra en la Rueda Bobán.

45. Calendario de Tovar, pl. 5. Véase la Rueda Bobán y el Vaticano A, f. 87r.

46. Rueda 4 de Veytia. El nombre también aparece en la Rueda núm. 5, Códice Vaticano A, fols. $87 \mathrm{r}$ y $87 \mathrm{v}$, calendario de Diego Durán, fol. 333v.

47. Bernardino de Sahagún, Primeros memoriales, fol. $252 \mathrm{r}$. 

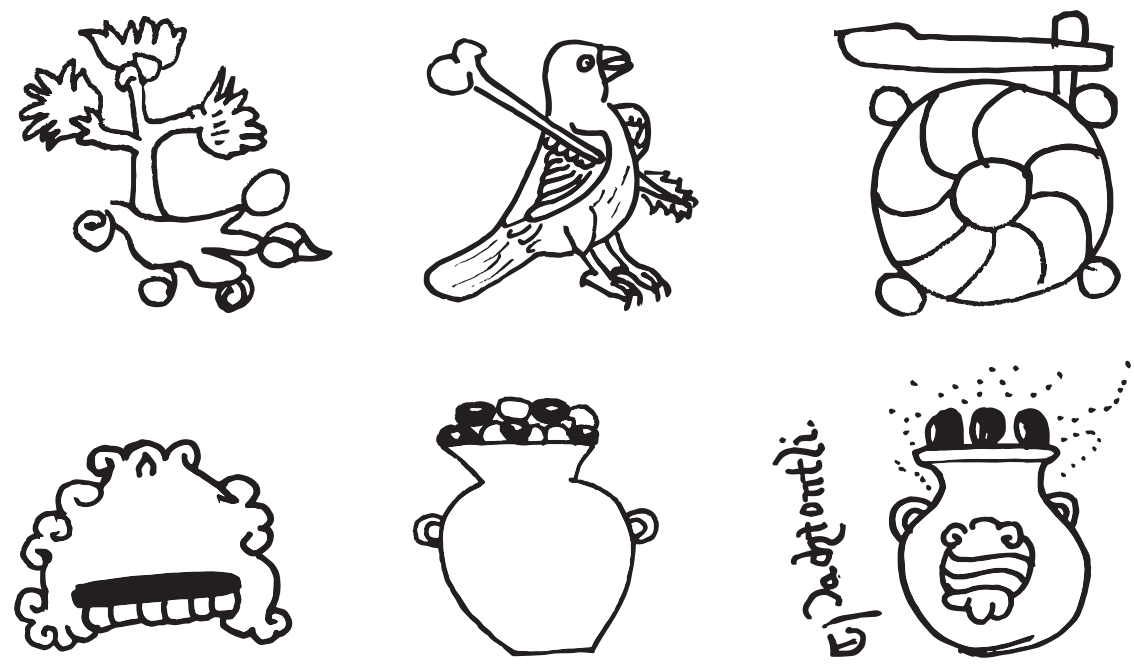

3. Ejemplos de los nombres de las veintenas reconstruidos en este estudio. (a) KwAW-a, $k^{w} a w[i t l e w] a, K^{w}$ awitlewa, "se levanta/asienta el árbol", basado en el Códice Vaticano A, fol. 87r.); (b) [WEI] TO-so Wei-tôsostli, Weitôsostli, "gran vigilia”, basado en el Calendario de Tovar,

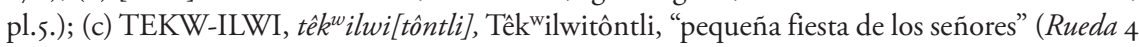
de Veytia); (d) TEPE, Tepêilwitl, Tepêilwitl, "fiesta de los cerros", basado en Sahagún, Primeros memoriales, f. 252r); (e) ETSA/ESA etsa[lkwalistli], Etsalkwalistli, "guiso de frijoles con maíz [llamado etsali]”, basado en el Códice borbónico, lám. 26); (f) te-e-E-ko, Teootleko, Teôtleko, 'sube el teôtl', basado en la Rueda Bobán. Dibujos: Ana Díaz.

este documento el glosista encargado de la transcripción en caracteres latinos escribió otro nombre para esta fiesta, el de la variante mexica Pachtôntli (ambas ubicadas en la posición I2 del xiwitl, véase el anexo documental, tablas 2 y 6). Este dato permite observar la participación de diferentes personajes en la creación de los documentos coloniales (fig. 3). El problema se aborda con mayor detalle en el siguiente apartado (véase también el anexo documental tabla 5).

Cabe mencionar que algunos de los glifos no pudieron identificarse, como sucede con el signo que aparece registrado sobre la casa en la veintena Iskalli, registrada en la Rueda Bobán. También resultan problemáticos los casos de Toxkatl y Tititl, cuya traducción también es difícil de establecer con certeza. Finalmente, la fiesta de Xokotlwetsi, de posible origen otomí, presenta una imagen que parece pertenecer a otro estatus, pues su carácter está más cercano al valor icónico que al escriturario. Es decir, la imagen del palo erguido consiste en una representación 
iconográfica profusa en detalles, aunque su valor fonético puede ser хоко, es muy aventurado asegurar esta identificación. Todos los casos analizados han sido integrados en la tabla 6 (anexo documental) incorporada al final de este texto.

Una consideración importante es que en las secuencias gráficas analizadas se pueden identificar claramente las dos tradiciones regionales que corresponden a la escuela de Tenochtitlan-Tlatelolco y la de Tetzcoco reportadas por Lacadena. ${ }^{8}$ Aunque ambas utilizan el mismo corpus de signos, en general la tradición tetzcocana favorece la transparencia fonética, y recurre a ciertas convenciones ortográficas que permiten reconstruir la lectura de una manera más directa que la tenochca, que presenta la información de manera más abreviada. El uso combinado de ambos repertorios se puede identificar en la Rueda Bobán, realizada en Tetzcoco. En ella aparecen los nombres de las fiestas celebradas en dicho âltepêtl escritas con escritura jeroglífica nahua, mientras que junto a los glifos se escribieron con caracteres latinos los nombres de las variantes mexicanas. Así, este ejemplar permite identificar dos momentos diferentes de escritura: el primero fue realizado por tlak $k^{w} \hat{l} \hat{\jmath} k e h$ tetzcocanos, quienes pudieron estar encargados también del registro de las imágenes. Posteriormente un glosista se encargó de escribir en náhuatl, pero con caracteres latinos, la transcripción de los nombres de las fiestas. Es importante señalar que este escriba no estaba familiarizado con las variantes tetzcocanas, por lo que escribió los nombres provenientes de otra tradición (véase la tabla 5, fig. 4).

La Rueda Bobán fue una pieza clave en la reconstrucción de la serie de las veintenas no sólo porque presenta estas dos versiones de nombres, sino porque consiste en un ejemplar que incluye una de las escasas representaciones de un xiwitl, porque añade el ciclo de los nêmontemi que permiten contar los 365 días del año (fig. 4). Estos elementos se incluyeron en la parte superior del códice, con la particularidad de que el $t l a k^{w}$ îlô registró los nombres de los nêmontemi de cuatro ańos consecutivos, lo que convierte este registro "anual" en una cuenta de 52 años, o xiwpôwalli, porque indica el nombre del signo portador de año con el que iniciará cada xiwitl. Cabe señalar que la composición gráfica de este códice tomó como modelo las ruedas calendáricas de la tradición cosmográfica cristiana. De esta manera, la Rueda Bobán integra las tres cuentas coloniales nahuas en una misma imagen, y genera una relación de equivalencia entre el año cristiano y el xiwitl (sin dejar afuera la cuenta de 52 años, fundamental para el sistema nahua). En conclusión, este material ofrece una correlación 


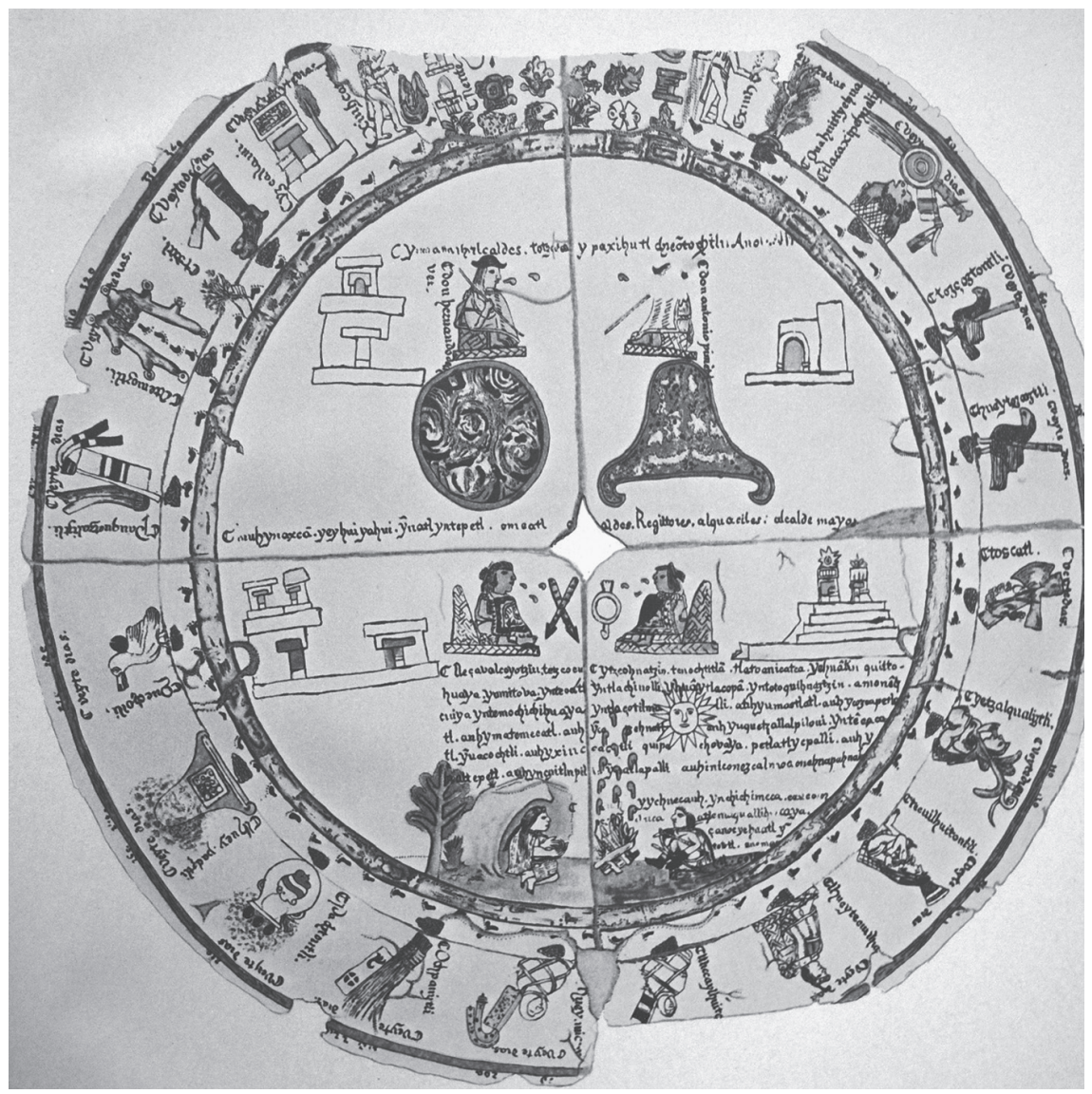

4. Rueda Bobán. Códice tetzcocano, siglo Xvı, tomado de Mariano Veytia, Calendarios Mexicanos, edición facsimilar (México: San Ángel, 1973 [1866]).

calendárica que, más allá de buscar una equivalencia entre las fechas del año nahua y el juliano, presenta una traducción de conceptos temporales que respeta las nociones básicas de ambos sistemas, y da lugar a una de las primeras imágenes del año nahua (específicamente el tetzcocano) y sus meses (fig. 4).

\section{Las variantes regionales del sêsemilwitlapôwalli}

Como se ha mencionado arriba, al analizar el corpus de documentos aparecieron diferentes variantes regionales. Por ejemplo, Âtlkâwalo también puede 
aparecer como Xilômanalistli y $\mathrm{K}^{\mathrm{w}}$ awitlewa, respectivamente. Esto se debe a que los documentos coloniales que explican el calendario contaron con la intervención de informantes y escribas de diferentes comunidades y tradiciones y estos tres nombres son lo que recibe el mismo ilwitl en diferentes lugares. Como los compiladores no intentaron precisar en su obra las variaciones regionales de las fiestas, la información que brindan no resulta muy precisa. Y así encontramos en el Códice Vaticano A, f. 42v que la imagen que hacía referencia a la ilwitl Âtlkâwalo, al glosarse se acompañó de la glosa $\mathrm{K}^{\mathrm{w}}$ awitlewa. Este cruce de información es bastante común en los documentos, como se ha referido anteriormente en la descripción de la Rueda Bobán.

Después de haber realizado el análisis de las glosas y los signos fue posible identificar la presencia de variantes regionales que se reflejan incluso al interior de una misma fuente, como se observa en la tabla 5 , donde se revisaron diferentes veintenas para ejemplificar esta dinámica de sustituciones. Para este estudio comparativo fue de gran utilidad la propuesta de reconstrucción regional ofrecida por Caso. ${ }^{49}$ Aunque al consultar cada fuente no fue posible encontrar un patrón tan definido y absoluto, como sugiere el estudio del autor, pues los glosistas de las fuentes coloniales refieren indistintamente a las variantes, aun dentro de un mismo documento. Esta dinámica se observa también en las deidades regentes de las veintenas (véase el anexo documental, tabla 4), que pueden cambiar dependiendo de la fuente consultada. Esta variedad de repertorios se explica si consideramos que los códices coloniales fueron producidos por escribanos y compositores de distinto origen y procedencia, quienes iban incorporando información en los escritos en diferentes momentos. Estas obras son colectivas, transculturales, resultado de complejos procesos creativos de reconfiguración y adaptación que implicaron ejercicios de ensayo y error para generar nuevos discursos y programas.

Este dato es significativo para comprender la manera en que las fuentes coloniales analizadas articulan diferentes voces con la intención de dar forma al nuevo calendario que estaba gestando; o mejor dicho, a nuevas maneras de comprender y explorar el funcionamiento de las cuentas antiguas del tiempo nahua para traerlas a la realidad novohispana. El mundo (el tiempo y su registro) estaban cambiando.

49. Para la reconstrucción de los repertorios de ambas regiones véase Alfonso Caso, Los calendarios, 38 . 


\section{Los nêmontemi}

El estudio reveló también que no parece haber existido un registro prehispánico para designar a los nêmontemi. Considero que este ciclo no se tomaba como ciclo, sino que sus días se podían seguir dentro de la cuenta del tônalli, como se refiere en la Rueda Bobán. Este dato se confirma en otros calendarios donde los cinco días "extra" se señalan como cuentas redondas que equivalen a cinco posiciones (Rueda 4 de Veytia), o bien se anotan como días normales de la cuenta calendárica (Calendario Tovar). Sólo el Telleriano Remensis los presenta representados como volutas de humo. Ambos registros son coloniales y dada la falta de unidad en el repertorio no considero que se trate de un elemento precolombino. Las volutas-nêmontemi del Códice Telleriano Remensis pueden explicarse como una adaptación de un elemento antiguo (humo), para ser resignificados en el contexto del cierre del ciclo anual..$^{50}$ De ser adecuada esta interpretación, el repertorio de glifos original nahua de nombres de veintenas no permitía reconstruir un xiwitl, sino un sêsemilwitlapôwalli. Así, para poder contar los días completos de un año habría que seguir los días del tônalpôwa$l l i$, que como se ha señalado anteriormente, son los únicos nombres que recibían los días en la cuenta nahua.

Los glifos del sêsemilwitlapôwalli iconizados en las obras novohispanas

Uno de los problemas a los que se enfrenta quien realice el análisis del corpus es que en un gran número de casos los glifos no pueden identificarse tan fácilmente, debido a que han sido integrados iconográficamente, pasando inadvertidos en el material. Como ejemplo puede mencionarse el logograma XIL, que aparece representado como una mazorca portada por la deidad de la ilwitl Xilômanalistli, ${ }^{\text {,I }}$ mientras el glifo de la veintena Tlâkaxîpêwalistli aparece adosado al friso del templo de Xipe Totec. ${ }^{52}$ La olla de etsalli, ETSA, toma un lugar secundario en la composición al ser portada por la deidad del agua en varios

50. Rafael Tena propone que una secuencia de ofrendas presentes en el repertorio de los códices Tudela-Magliabechiano puede estar representando el ciclo de los cinco nêmontemi. Véase Tena, El calendario mexica y la cronografía (México: Instituto Nacional de Antropología, 1987), 6I-69. En mi estudio no encontré ningún elemento que permita hacer esta identificación.

51. Códice Tudela, fol. IIr.

52. Códice florentino, t. I, fol. $26 \mathrm{r}$. 
de los documentos coloniales. ${ }^{53}$ Aunque en otros casos aparece simplemente como un objeto más dentro de la compleja escenificación de la fiesta, ${ }^{54}$ al igual que las flores de Tlaxôchimâco. 55 El cerro de Tepêilwitl es otro de los signos que pueden aparecer insertos en una secuencia figurativa, ${ }^{56}$ lo que dificulta su contextualización como glifo escriturario. Las veintenas Mikâilwitôntli y Weimikâilwitl, que son representadas con el glifo MIK, ${ }^{57}$ o con un glifo que muestra un bulto mortuorio, ${ }^{58}$ pueden reinterpretarse como deidades muertas.

Un caso peculiar aparece en estos dos documentos, donde el glifo TEP/TEPE fue personificado por el pintor al colocarle la máscara del dios de la lluvia; este ingenioso recurso se repite en la representación del ilwitl Âtemôstli, ${ }^{59}$ donde la máscara se sobrepuso a un chorro de agua que desciende, y que corresponde a otro de los glifos utilizados por los escribas de la escuela de Tenochtitlan para designar a esta veintena. El uso de estas máscaras permitió al pintor incorporar la secuencia del sêsemilwitlapôwalli como una serie de deidades, relacionadas con cada uno de los meses. Tal como sucede en los ejemplares europeos que muestran el calendario mensual de las antiguas civilizaciones paganas.

Posiblemente el caso más sobresaliente de la manipulación del repertorio del sêsemilwitlapôwalli se encuentra en el calendario registrado en la Historia de Durán, donde los glifos se insertaron en nubes y se reinterpretaron acorde a las disposiciones formales propias de la pintura europea. El caso más evidente es la personificación de Tláloc-chorro de agua descendente, a quien se ha reinterpretado como una deidad del panteón clásico romano, vestido con una túnica roja y descendiendo de una bóveda celeste estrellada (fig. 5).

En la tabla 2 (anexo documental) se ha especificado en qué casos aparecen los glifos de cada ilwitl representado como un signo del repertorio original y en qué casos se integraron en la iconografía de la composición, cambiando parcialmente su naturaleza de glifo a icono. Con esta diferenciación signol

53. Códice borbónico, Códice Magliabechiano, fol. 34r; Códice Vaticano A, fol. 5or; Calendario Durán fol. 33v; Calendario Tovar.

54. Códice borbónico, lám. 26; Códice florentino, t. I, fol. 45.

55. Códice borbónico, lám. I8; Códice Tudela, fol. I9r; Calendario Tovar.

56. Primeros memoriales, fol. 252r; Códice Tudela, fol. 23r, Códice Magliabechiano, fol. 4rr; Códice borbónico, lám. 32.

57. Rueda de Veytia núm. 4.

58. Tal como aparecen en los códices Telleriano Remensis y Vaticano A. Véase también la Rueda Bobán y el Calendario de Durán.

59. Códice Telleriano Remensis, fol. $5 \mathrm{v}$. 

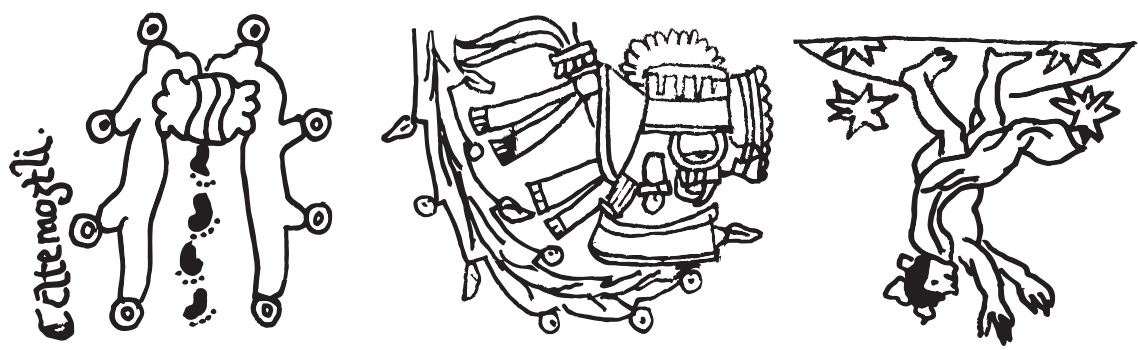

5. Transformación del registro gráfico de Âtemôstli. a) Escritura jeroglífica de tradición tetzcocana: a-te-TEMO, a [a]temo[ostli], Âtemôstli (Rueda Bobán); b) iconización del nombre Âtemôstli: el chorro de agua que desciende (a-TEMO) se personificó con la máscara de Tláloc, convirtiéndolo en una deidad (Códice Telleriano Remensis, fol.5v); c) iconización y resignificación iconográfica del texto (a-TEMO) para transformarlo en la personificación de una deidad clásica del panteón mexicano, representada bajo los cánones figurativos europeos (Calendario de Durán en Historia eclesiástica, f. 342r). Dibujos: Ana Díaz.

signo iconizado se pretende tener una mayor precisión al abordar el estudio del ciclo.

¿Cuáles son las implicaciones de este cambio de códigos? El paso de un signo escriturario a una imagen icónica es interesante, pues permite proponer que el repertorio de glifos es anterior al contacto con los españoles. Como los escribas y pintores debieron explicar su mundo a los ojos de los recién llegados, una de las soluciones formales consistió en transformar los códigos para lograr una adecuación con los recursos europeos. Como resultado, las imágenes se adaptaron a las nuevas disposiciones formales y los glifos se volvieron iconos, como sucedió en su momento con los signos del zodiaco (en este punto concuerdo con Brown). De este modo, las imágenes se colocaron en el cajón que les correspondía, epistemológicamente hablando, dentro del contexto europeo. Pero ¿cuál fue la razón para que este repertorio de signos se mantuviera vigente, replanteándose en lo formal, a diferencia del ciclo de signos del tônalpôwalli que no sufrió modificaciones en su registro? Es posible que la respuesta se encuentre en la reconstrucción del calendario indígena generada a partir de la visión europea; mientras los 20 glifos del tônalpôwalli se incluyeron en las fuentes coloniales que explicaban el calendario con la única intención de que los frailes los conocieran y pudieran erradicarlos del culto, el ciclo del sêsemilwitlapôwalli, identificado con los meses del año civil, se transformó para adaptarse al ciclo figurativo de los meses europeos. Esto se posibilitó porque 


\section{I76 ANA DÍAZ}

ambos sistemas se asimilaron como un mismo referente. En ello sí coincido con autores como Brown, Kubler y Gibson pues efectivamente durante la colonia se dio una reconfiguración del imaginario de las veintenas. Sólo que este fenómeno parece haber ocurrido no en una sola dirección, como lo sugieren los autores arriba referidos, para quienes el sistema glífico se generó después de que los indígenas entraron en contacto con los registros escriturarios españoles. Propongo que la reconfiguración de los "meses" nahuas fue un movimiento complejo que involucró la adaptación y manipulación de los repertorios de veintenas nahuas y de los calendarios europeos, dependiendo de las necesidades de los compositores de cada fuente. Es decir, no fue un proceso homogéneo que haya permitido mostrar el calendario prehispánico original, como tampoco fue un proceso homogéneo de sistematización que diera pie a un nuevo repertorio perfectamente articulado.

\section{Conclusión}

El objetivo de este trabajo ha sido analizar la transformación de un repertorio de signos nahuas utilizados para designar a las veintenas en época prehispánica, para ubicar su uso, adaptación y reconfiguración a las fuentes coloniales siguiendo el paradigma temporal novohispano. La integración de datos provenientes de una muestra representativa de códices permitió reconstruir un repertorio de signos escriturarios antiguos, cuya función era designativa, en contraste con los sistemas de notación calendárica tradicionales del centro de México.

Los casos estudiados permiten observar que, al pasar los datos de las fuentes precolombinas a las novohispanas, se generó un complejo proceso de reconfiguración, nada homogéneo, que derivó en la creación de diferentes repertorios gráficos, producto de esfuerzos colectivos. Cada códice analizado parece haber involucrado la participación de diversos agentes, quienes intervinieron en el proceso de traducción y adaptación de conceptos e imaginarios del mundo nahua antiguo para hacerlos visibles a los lectores a quienes estaban destinados los códices coloniales. Así se pasó de un sistema de registro notacional (escritura logográfica), a los ciclos figurativos propios del calendario anual universal: los dioses y las fiestas.

Más allá de ofrecer una reconstrucción definitiva de todos los nombres de las veintenas y sus variantes, como pudieron utilizarse en fechas prehispánicas, el presente trabajo abre una invitación para repensar la función y el uso de los 
registros gráficos del xiwitl, el sêsemilwitlapôwalli y sus partes constitutivas en el contexto de un diálogo transcultural muy complejo. Considero que los datos ofrecidos en las descripciones coloniales (textos e imágenes) no permiten hacer una reconstrucción absoluta y coherente de los sistemas de cómputo temporal prehispánico; aunque aportan datos fundamentales para comprender aspectos de un proceso de traducción y diálogo. El estudio de los ejemplares permitió hacer un seguimiento de las soluciones elegidas por distintos autores, quienes intentaron traducir conceptos conflictivos, dar coherencia a fenómenos ajenos a los paradigmas de la tradición cronológica propia, e integrar variaciones locales dentro de explicaciones universalizantes para reconfigurar el rostro del antiguo calendario mexicano. \&

N.B. Este estudio se vio enriquecido con los comentarios de Erik Velásquez y Alfonso Lacadena, a quienes agradezco su apoyo, fundamental para comprender los principios de la técnica escrituraria. Agradezco también al Proyecto PAPIIT IN402213, "Las escrituras jeroglíficas maya y náhuatl: desciframiento, análisis y problemas actuales", así como a Leopoldo Valiñas por haber compartido conmigo su texto relativo a la normalización del náhuatl clásico y por sus sugerentes comentarios. 
DOI: http://dx.doi.org/10.22201/iie.18703062e.2018.113.2653 
DOI: http://dx.doi.org/10.22201/iie.18703062e.2018.113.2653

Anexo documental

Tabla I. Nombres de los 20 signos del tônalpôwalli

\begin{tabular}{|c|c|c|c|}
\hline I. & Sipaktli & $=$ & Lagarto \\
\hline II. & Ehêkatl & $=$ & viento \\
\hline III. & Kalli & $=$ & casa (portador de año) \\
\hline IV. & $\mathrm{K}^{\mathrm{w}}$ etspallin & $=$ & lagartija \\
\hline V. & Kôâtl & $=$ & serpiente \\
\hline VI. & Mikistli & $=$ & muerte \\
\hline VII. & Masâtl & $=$ & venado \\
\hline VIII. & Tôchtli & $=$ & conejo (portador de año) \\
\hline IX. & Âtl & $=$ & agua \\
\hline $\mathrm{X}$. & Itsk $\mathrm{w}^{\mathrm{in}} \mathrm{tli}$ & $=$ & perro \\
\hline XI. & Osomatli & $=$ & mono \\
\hline XII. & Malînalli & $=$ & hierba (hierba jabonera o para hacer escobas) \\
\hline XIII. & Âkatl & $=$ & cańa (portador de año) \\
\hline XIV. & Osêlôtl & $=$ & jaguar \\
\hline $\mathrm{XV}$. & $\mathrm{K}^{\mathrm{w}}$ âwtli & $=$ & águila \\
\hline XVI. & Kôskak ${ }^{w} a ̂ w t l i$ & $=$ & zopilote \\
\hline XVII. & Ôllîn & $=$ & movimiento \\
\hline XVIII. & Tekpatl & $=$ & pedernal (portador de año) \\
\hline XIX. & Kiyawitl & $=$ & lluvia \\
\hline XX. & Xôchitl & $=$ & flor \\
\hline
\end{tabular}


Tabla 2. Nombres de las veintenas

\begin{tabular}{|c|c|}
\hline I.I. Âtlkâwalo & $=$ "detención de aguas". \\
\hline I.2. $\mathrm{K}^{\mathrm{w}}$ awitlewa & $=$ "se levanta/asienta el árbol". \\
\hline I.3. Xilômanalistli & $=$ "ofrecimiento de jilotes". \\
\hline 2. Tlâkaxîpêwalistli & $=$ "desollamiento de gente". \\
\hline 3. Tôsostôntli & $=$ "pequeña vigilia". \\
\hline 4. Weitôsostli & $=$ "gran vigilia". \\
\hline 5. Toxkatl & $\begin{aligned}= & \text { sin traducción clara. Según Caso (Los Calendarios prehispánicos) } \\
& \text { podría ser "cosa seca". }\end{aligned}$ \\
\hline 6. Etsalkwalistli & $=$ "guiso de frijoles con maíz [llamado etsalli]". \\
\hline 7. Têkwilwitôntli & $=$ "pequeña fiesta de los señores". \\
\hline 8. Weitêk ${ }^{\mathrm{w}}$ ilwitl & $=$ "gran fiesta de los señores". \\
\hline 9.I. Mikâilwitôntli & $=$ "pequeña fiesta de los muertos". \\
\hline 9.2. Tlaxôchimâko & $=$ "se dan de flores". \\
\hline Io.I. Weimikâilwitl & $=$ "gran fiesta de los muertos". \\
\hline IO.2. Xokotlwetsi & $\begin{array}{l}=\text { sin traducción clara. Según Thelma Sullivan (Compendio de } \\
\text { la gramática kāhmatl) es xiw-okotl, "año-ocote", "el ocote del } \\
\text { xiwitl". Según Caso, Los calendarios prehispánicos se traduce como } \\
\text { "cae el fruto". }\end{array}$ \\
\hline II. Ochpânistli & $=$ "barrimiento". \\
\hline I2.I. Pachtôntli & $=$ "pequeño pachtli $[$ heno]". \\
\hline I2.2. Teôtleko & $=$ "sube el teôtl". \\
\hline I3.I. Weipachtli & $=$ "gran pachtli $[$ heno]". \\
\hline I3.2. Tepêilwitl & $=$ "fiesta de los cerros". \\
\hline I4. Kechôlli & $=$ "espátula rosa" (ave similar al flamingo). \\
\hline I5. Pânketsalistli & $=$ "levantamiento de banderas". \\
\hline I6. Âtemôstli & $=$ "descendimiento de agua". \\
\hline I7. Tititl & $=$ "estirar". \\
\hline I8. Iskalli & $\begin{array}{l}=\text { sin traducción clara. En distintas fuentes se traduce como: } \\
\text { "reavivar", "resucitar", "adiestrar", "crecer" (véase GDN). Caso, Los } \\
\text { calendarios prehispánicos lo traduce como "resurrección". }\end{array}$ \\
\hline
\end{tabular}

Algunas veintenas reciben diferentes nombres, por eso se colocaron dos numerales para identificar la posición que éstos ocupan dentro del sistema. El primer dígito indica la posición que ocupa la veintena en el xiwitl y el segundo dígito, ubicado después del punto, se refiere el número de variante de la veintena. 


\section{I8I}

Tabla 3. Análisis del tipo de registro que presentan las veintenas en las fuentes coloniales

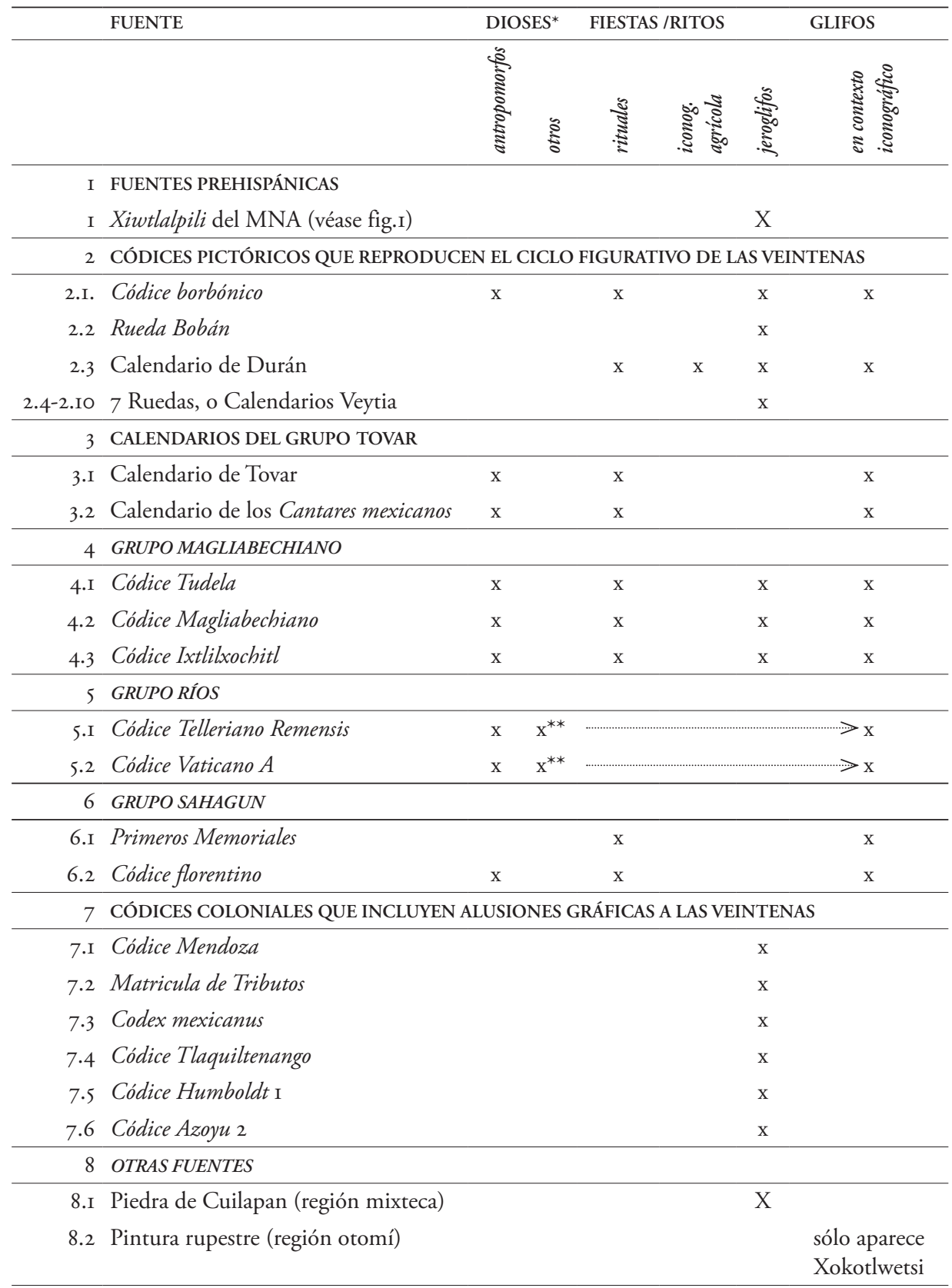


I82

Tabla 4. Deidades regentes de las veintenas en los repertorios pictóricos

\begin{tabular}{|c|c|c|c|c|}
\hline & \multirow[t]{2}{*}{ VEINTENA } & \multirow{2}{*}{$\begin{array}{c}\text { Gpo. CÓDICES } \\
\text { C. Borbónico }\end{array}$} & \multicolumn{2}{|c|}{ Gpo. MAGLIABECHIANO } \\
\hline & & & C. Tudela & C. Magliabechiano \\
\hline I & $\begin{array}{l}\text { Âtlkaâwalo / } \\
\text { Xilômanalistli / } \\
\text { Kwawitlewa }\end{array}$ & Tláloc & Tláloc & Tláloc \\
\hline 2 & Tlâkaxîpêwalistli & Xipe-Totec & Xipe-Totec & Xipe-Totec \\
\hline 3 & Tôsostôntli & Tláloc & $\begin{array}{l}\text { Chalchiuhtlicue?. La glosa } \\
\text { dice: "tezcacohuac tziua } \\
\text { pipiltin" (f. I3r). }\end{array}$ & Chicomecoatl \\
\hline 4 & Weitôsostli & Tláloc & $\begin{array}{c}\text { Deidad femenina, La } \\
\text { glosa dice que se honraba } \\
\text { a Cintétol y Quetzalcoatl } \\
\text { (f. I4r). }\end{array}$ & $\begin{array}{l}\text { No aparecen } \\
\text { personajes, sólo } \\
\text { objetos rituales }\end{array}$ \\
\hline 5 & Toxkatl & $\begin{array}{c}\text { Cihuacoatl, } \\
\text { Xiuhtecuhtli, Mixcoatl, } \\
\text { Tezcatlipoca } \\
\end{array}$ & Tezcatlipoca & Tezcatlipoca \\
\hline $\mathrm{g}$ & Etsalkwalistli & $\begin{array}{c}\text { Xolotl, Tláloc, } \\
\text { Quetzalcoatl }\end{array}$ & Tláloc & Tláloc \\
\hline 7 & Têkwilwitôntli & $\begin{array}{l}\text { Ixtlilton, Cinteotl, } \\
\text { Quetzalcoatl, } \\
\text { Cihuacoatl? }\end{array}$ & Xochipilli & Xochipilli \\
\hline 8 & Weitêkwilwitl & Xochipilli, Xipe-Totec & Chicomecoatl & Xilonen \\
\hline 9 & $\begin{array}{l}\text { Mikâilwitôntli / } \\
\text { Tlaxôchimâko }\end{array}$ & $\begin{array}{c}\text { Xiuhtecuhtli* } \\
\text { Cihuacoatl, Mixcoatl }\end{array}$ & $\begin{array}{c}\text { Tezcatlipoca (la glosa } \\
\text { identifica a Tlaxuchimaco } \\
\text { con un dios "que es todos } \\
\text { los demonios juntos" (f. rgr). }\end{array}$ & Tezcatlipoca \\
\hline IO & $\begin{array}{l}\text { Weimikâilwitl/ } \\
\text { Xokotlwetsi }\end{array}$ & $\begin{array}{l}\text { palo de Xokotl } \\
\text { (posiblemente } \\
\text { Xiuhtecuhtli) }\end{array}$ & $\begin{array}{c}\text { palo de Xokotl } \\
\text { (posiblemente Xiuhtecuhtli) }\end{array}$ & $\begin{array}{l}\text { palo de Xokotl } \\
\text { (posiblemente } \\
\text { Xiuhtecuhtli) }\end{array}$ \\
\hline II & Ochpânistli & Toci, Chicomecoatl & Toci, Xiuhtecuhtli & Toci \\
\hline I2 & $\begin{array}{l}\text { Pachtôntli / } \\
\text { Teôtleko }\end{array}$ & $\begin{array}{c}\text { Chicomecoatl azul, } \\
\text { diosa del agua y } 4 \\
\text { tlaloque }\end{array}$ & $\begin{array}{l}\text { Mixcoatl (glosa: Tlacamaz, } \\
\text { sacerdote del diablo 22r) }\end{array}$ & $\begin{array}{c}\text { no se identifica } \\
\text { (glosa: Ometochtli } \\
\text { f. } 39 v \text { ) }\end{array}$ \\
\hline I3 & $\begin{array}{l}\text { Weipachtli / } \\
\text { Tepêilwitl }\end{array}$ & Tláloc & Chicomecoatl & Chicomeoatl \\
\hline
\end{tabular}




\begin{tabular}{|c|c|c|c|c|}
\hline Gpo. RÍOS & \multicolumn{2}{|c|}{ Gpo. SAHAGÚN } & \multicolumn{2}{|c|}{ Gpo.TOVAR } \\
\hline C. Vat. A y T.R. & P. Memoriales & C. Florentino & Cal.Durán & Cal. Tovar \\
\hline $\begin{array}{c}\text { Árbol con máscara de } \\
\text { Tláloc }\end{array}$ & Tláloc? & ninguno & ninguno & ninguno \\
\hline Xipe-Totec & Xipe-Totec & Xipe-Totec & Xipe-Totec & Xipe-Totec \\
\hline Chicomecoatl & ninguno & $\begin{array}{l}\text { no se menciona la } \\
\text { fiesta en la segunda } \\
\text { sección del capítulo }\end{array}$ & $\begin{array}{l}\text { ninguno (hay } \\
\text { error en la glosa, } \\
\text { la identifica como } \\
\text { Ochpaniztli) }\end{array}$ & ninguno \\
\hline $\begin{array}{l}\text { Chicomecoatl o } \\
\text { Cinteotl? }\end{array}$ & Chicomecoatl & Chicomecoatl & ninguno & ninguno \\
\hline Tezcatlipoca & $\begin{array}{l}\text { Tezcatlipoca y } \\
\text { Yacatecuhtli }\end{array}$ & Tezcatlipoca & $\begin{array}{c}\text { Huitzilopochtli? } \\
\text { (lámina } \\
\text { incompleta) }\end{array}$ & $\begin{array}{c}\text { Tezcatlipoca } \\
\text { (rostro y espejo de } \\
\text { obsidiana) }\end{array}$ \\
\hline Tláloc & Tláloc? & ninguno & $\begin{array}{c}\text { Tláloc } \\
\text { (europeizado) }\end{array}$ & Tláloc \\
\hline $\begin{array}{l}\text { Diosa de la sal o del } \\
\text { agua }\end{array}$ & $\begin{array}{l}\text { Uixtocihuatl } \\
\text { (diosa de la sal) }\end{array}$ & $\begin{array}{l}\text { Uixtocihuatl (diosa } \\
\text { de la sal) }\end{array}$ & $\begin{array}{l}\text { ninguno (es un } \\
\text { señor) }\end{array}$ & $\begin{array}{l}\text { ninguno (es un } \\
\text { seńor) }\end{array}$ \\
\hline ninguno (es un señor) & Xilonen & ninguno & $\begin{array}{l}\text { ninguno (es un } \\
\text { señor) }\end{array}$ & $\begin{array}{l}\text { ninguno (es un } \\
\text { señor) }\end{array}$ \\
\hline $\begin{array}{l}\text { Bulto mortuorio. } \\
\text { Xiuhtecuhtli-Paynal- } \\
\text { ¿Otontecuhtli? }\end{array}$ & sin identificar & Huitzilopochtli & ninguno & ninguno \\
\hline $\begin{array}{l}\text { Xiuhtecuhtli como } \\
\text { bulto mortuorio }\end{array}$ & $\begin{array}{l}\text { palo de Xokotl } \\
\text { (posiblemente } \\
\text { Xiuhtecuhtli) }\end{array}$ & $\begin{array}{l}\text { no hay imagen de la } \\
\text { fiesta }\end{array}$ & $\begin{array}{l}\text { palo de Xokotl } \\
\text { (posiblemente } \\
\text { Xiuhtecuhtli) }\end{array}$ & $\begin{array}{l}\text { palo de Xokotl } \\
\text { (posiblemente } \\
\text { Xiuhtecuhtli) }\end{array}$ \\
\hline Toci & Toci & $\begin{array}{l}\text { no hay imagen de la } \\
\text { fiesta }\end{array}$ & Toci & ninguno \\
\hline Tezcatlipoca & no identificado & ninguno & ¿Cihuacoatl? & ninguno \\
\hline $\begin{array}{c}\text { Cerro con máscara de } \\
\text { Tlaloc }\end{array}$ & Cerros & $\begin{array}{l}\text { no hay imagen de la } \\
\text { fiesta }\end{array}$ & $\begin{array}{l}\text { ninguno, aparece } \\
\text { una serpiente }\end{array}$ & Cerro \\
\hline
\end{tabular}


DOI: http://dx.doi.org/10.22201/iie.18703062e.2018.113.2653

I84

\begin{tabular}{|c|c|c|c|c|}
\hline & \multirow[t]{2}{*}{ VEINTENA } & Gpo. CÓDICES & \multicolumn{2}{|c|}{ Gpo. MAGLIABECHIANO } \\
\hline & & C. Borbónico & C. Tudela & C. Magliabechiano \\
\hline I4 & Kechôlli & Mixcoatl, Tezcatlipoca & Mixcoatl & Mixcoatl \\
\hline I5 & Pânketsalistli & $\begin{array}{l}\text { Varios dioses (Fuego } \\
\text { Nuevo) }\end{array}$ & Huitzilopochtli & Huitzilopochtli \\
\hline & Âtemôstli & $\begin{array}{c}\text { Tláloc y } \\
\text { Chalchiuhtlicue }\end{array}$ & Tláloc y lluvia & Tláloc y lluvia \\
\hline I7 & Tititl & $\begin{array}{c}\text { Cihuacoatl, doce dioses } \\
\text { y un bulto }\end{array}$ & Cihuacoatl & Cihuacoatl \\
\hline & Iskalli & $\begin{array}{l}\text { Cihuacoatl y } \\
\text { Xiuhtecuhtli }\end{array}$ & $\begin{array}{l}\text { Xiuhtecuhtli (glosa: } \\
\text { Izcozauhque) }\end{array}$ & Xiuhtecuhtli \\
\hline
\end{tabular}

No hay unidad en su representación. El ciclo aparece en el códice Telleriano Remensis (como volutas de humo); en la Rueda 5 de Veytia (como cuentas redondas, identificando cinco días bajo la tradición iconográfica indígena);

nêmontemi en la Rueda Bobán (como días marcados con su signo-toonali, a diferencia de la Rueda de Veytia); y en el Calendario de Tovar (como días marcados con las letras dominicales. Este ciclo se acompaña de un sacerdote que no aparece en otras fuentes). 
DOI: http://dx.doi.org/10.22201/iie.18703062e.2018.113.2653

185

\begin{tabular}{|c|cc|cc|}
\hline Gpo. RÍOS & \multicolumn{2}{|c|}{ Gpo. SAHAGÚN } & \multicolumn{2}{c|}{ Gpo.TOVAR } \\
\hline C. Vat. A y T.R. & P. Memoriales & C. Florentino & Cal.Durán & Cal. Tovar \\
\hline Mixcoatl & Mixcoatl & $\begin{array}{c}\text { no hay imagen de la } \\
\text { fiesta }\end{array}$ & Mixcoatl & Mixcoatl \\
\hline Tezcatlipoca & Huitzilopochtli & $\begin{array}{c}\text { Huitzilopochtli? } \\
\text { Representación } \\
\text { europea }\end{array}$ & ninguno & ninguno \\
\hline $\begin{array}{c}\text { Chorro de agua con } \\
\text { máscara de Tláloc } \\
\text { personajes, } \\
\text { gotas de lluvia }\end{array}$ & $\begin{array}{c}\text { no hay imagen de la } \\
\text { fiesta } \\
\text { Deidad femenina } \\
\text { glosa: Xochiquetzal } \\
\text { (f.6r) }\end{array}$ & Cihuacoatl & $\begin{array}{c}\text { dios europeo que } \\
\text { desciende del } \\
\text { cielo**** }\end{array}$ & Tláloc y lluvia \\
\hline $\begin{array}{c}\text { Xiuhtecuhtli } \\
\text { ninguno }\end{array}$ & Xiuhtecuhtli & ninguno & ninguno & ninguno \\
\hline \multicolumn{2}{|c|}{ ninguno } \\
\hline
\end{tabular}


DOI: http://dx.doi.org/10.22201/iie.18703062e.2018.113.2653

\section{I86}

Tabla 5. Comparación entre los nombres escritos con escritura jeroglífica y nombres escritos con caracteres latinos en un mismo documento

\begin{tabular}{cll}
\hline $\begin{array}{c}\text { Grupo } \\
\text { (véase la tabla 3) }\end{array}$ & \multicolumn{1}{c}{ Fuente } & \multicolumn{1}{c}{ nombre escrito con jeroglíficos nahuas } \\
\hline 2.1 & Códice Borbónico & Xilômanalistli, Tlaxôchimâko, Teôtleko \\
2.2 & Rueda de Boban & Kwawitlewa, Mikâilwitôntli, Tepêilwitl \\
2.3 & Calendario de Durán & $\begin{array}{l}\text { Kwawitlewa; Weimikâilwitl y Xocotlwetsi combinadas; } \\
\text { Weipachtli y Kôâilwitl aparecen combinadas }\end{array}$ \\
& Rueda 4 de Veytia & Âtlkâwalo, Mikâilwitôntli Pachtôntli \\
2.7 & Rueda 5 de Veytia & $\begin{array}{l}\text { Xilômanalistli, Kôâilwiitl (en el lugar de } \\
\text { Tlâkaxîpêwalistli) }\end{array}$ \\
& Gpo RÍOS & Kwawitlewa, Mikâilwitôntli , Teôtleko \\
\end{tabular}


DOI: http://dx.doi.org/10.22201/iie.18703062e.2018.113.2653

nombres como aparecen escritos con alfabeto latino

no hay glosas

Cuahuit[ilegible], Micailhuitontli, Hueypachtli

[?]cuitlehua (no es veintena); jocotlhuetz; ueypachtli y coaylhuitl

Están intercalados los nombres de las veintenas 7-IO y I2-I3

Xilomaniztli, Cohuailhuitl (si corresponde a la escritura glífica)

Atlcahualo, Micailhuitl, Pachtontli (los últimos 2 nombres corresponden a distintas series) 
DOI: http://dx.doi.org/10.22201/iie.18703062e.2018.113.2653

I88

Tabla 6. Reconstrucción de la lectura del repertorio gráfico del seesemilwitlapoowali

\begin{tabular}{|c|c|c|c|}
\hline No. & Ilwitl & Transliteración & Transcripción \\
\hline \multirow{3}{*}{ I } & $\begin{array}{l}\text { Âtlkâwalo "detención de } \\
\text { aguas" }\end{array}$ & $a-?$ & a[tl kawalo] \\
\hline & $\begin{array}{c}\text { Kwawitlewa "se alza el } \\
\text { árbol" }\end{array}$ & KwAW- a & kwaw[itlew]a \\
\hline & $\begin{array}{c}\text { Xilômanalistli } \\
\text { "ofrecimiento de jilotes" }\end{array}$ & XILO & xilo[manalistli] \\
\hline 2 & $\begin{array}{c}\text { Tlâkaxîpêwalistli } \\
\text { "desollamiento de gente" }\end{array}$ & XIPE & [Tlaca]xipe[walistli] \\
\hline \multirow{2}{*}{3} & $\begin{array}{l}\text { Tôsostôntli "pequeña } \\
\text { vigilia”" }\end{array}$ & to-so & toso[stontli] \\
\hline & $\begin{array}{l}\text { Tôsostôntli "pequeña } \\
\text { vigilia”" }\end{array}$ & TOS & $\begin{array}{l}\text { tos[ostontli] en la fuente aparece como: } \\
\text { tos [cotzintli] }\end{array}$ \\
\hline \multirow{3}{*}{4} & Weitôsostli "gran vigilia" & [wei] to-so & $\begin{array}{c}\text { wei toso[stli] La partícula WEI se indica con } \\
\text { el tamaño mayor de los signos }\end{array}$ \\
\hline & Weitôsostli "gran vigilia" & [wei] TOS & $\begin{array}{l}\text { wei tos[ostli] (La fuente dice: } \\
\text { "huei toscozintli") }\end{array}$ \\
\hline & Weitôsostli "gran vigilia" & $?$ & $?$ \\
\hline 5 & Toxkatl & $?$ & $?$ \\
\hline \multirow[t]{2}{*}{6} & $\begin{array}{l}\text { Etsalkwalistli "guiso de } \\
\text { frijoles con maíz [etsali]" }\end{array}$ & ETSAL & etsal[lkwalistli] \\
\hline & $\begin{array}{l}\text { Etsalk }^{\mathrm{w}} \text { alistli "guiso de } \\
\text { frijoles con maíz [etsali]" }\end{array}$ & & \\
\hline
\end{tabular}




\begin{tabular}{|c|c|c|}
\hline $\begin{array}{l}\text { Casos } \\
\text { Registrados }\end{array}$ & $\begin{array}{l}\text { Ubicación } \\
\text { En fuentes }\end{array}$ & Apariciones \\
\hline I & Veytia rueda 4. & \\
\hline 5: 2 signos, 3 signos iconizados & $\begin{array}{l}\text { Vaticano A 87r (y 42v) Duran (343v), } \\
\text { Tovar(XIV), Rueda de Boban, }\end{array}$ & II \\
\hline 5: 2 signos, 3 signos iconizados & $\begin{array}{l}\text { Veytia ruedas, Borbónico(lam23), Tudela(IIr), } \\
\text { Magliabechiano (29r) Ixtlilxochitl(94r). }\end{array}$ & \\
\hline $\begin{array}{c}6 \text { signos.otros documentos } \\
\text { presentan al dios Xipe o alguno } \\
\text { de sus atributos }\end{array}$ & $\begin{array}{c}\text { Florentino(26r), Vaticano A(87r), Veytia rueda } \\
\text { 4, Mat. de Tributos(25), Mendocino(47r), } \\
\text { Humboldt I. }\end{array}$ & 6 \\
\hline 4: 3signos, I signo iconizado & $\begin{array}{l}\text { Rueda de Boban, Vaticano A (87r), } \\
\qquad \operatorname{Duran}(328 r) \operatorname{Tovar}(V) \text {. }\end{array}$ & \\
\hline I & rueda 5 de Veytia. & 5 \\
\hline 4: 3 signos, I signo iconizado & $\begin{array}{l}\text { Calendario de Tovar, Rueda de Boban, } \\
\text { Vaticano A(87r), Duran(328r). }\end{array}$ & \multirow{3}{*}{7} \\
\hline I & Rueda 5 de Veytia. & \\
\hline 2 & Rueda 4 de Veytia, Vaticano A (87r). & \\
\hline - & $\begin{array}{l}\text { no hay unidad en la muestra. No se pudo } \\
\text { reconstruir la lectura. }\end{array}$ & $x-$ \\
\hline II: 6 signos y 5 signos iconizados & $\begin{array}{l}\text { Borbónico (26), Magliabechiano(34r), } \\
\text { Ixtlilxochitl(96v), Vaticano A(5or, 87r y 87v), } \\
\text { Florentino(45v), Duran(33rv), Tovar(VI) Rueda } \\
\text { 4 de Veytia, Rueda } 5 \text { de Veytia. }\end{array}$ & \multirow[t]{2}{*}{ I2 } \\
\hline I & Humboldt I. & \\
\hline
\end{tabular}


DOI: http://dx.doi.org/10.22201/iie.18703062e.2018.113.2653

I90

\begin{tabular}{|c|c|c|c|}
\hline No. & Ilwitl & Transliteración & Transcripción \\
\hline \multirow[t]{2}{*}{7} & $\begin{array}{l}\text { Têkwilwitôntli “pequeña } \\
\text { fiesta de los señores" }\end{array}$ & $\begin{array}{c}\text { TEKw-ILWI } \\
\text { *Puede aparecer } \\
\text { sólo el logograma } \\
\text { TEKw }\end{array}$ & tekwilit[tontli] \\
\hline & $\begin{array}{l}\text { Têk'wilwitôntli “pequeña } \\
\text { fiesta de los señores"” }\end{array}$ & \multicolumn{2}{|c|}{ *No es glifo con valor fonético, es un ícono. } \\
\hline 8 & 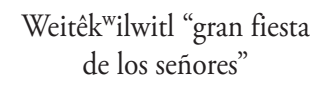 & $\begin{array}{l}\text { (WEI) } \\
\text { TEKw-ILWI }\end{array}$ & $\begin{array}{l}\text { [Wei] tekwilwitl. La partícula WEI se indica } \\
\text { con el tamaño mayor de los signos. }\end{array}$ \\
\hline \multirow[t]{3}{*}{9} & $\begin{array}{l}\text { Mikâilwitôntli "pequeńa } \\
\text { fiesta de los muertos" }\end{array}$ & MIK? & mik[ailhuitontli] \\
\hline & $\begin{array}{l}\text { Mikâilwitôntli "gran fiesta } \\
\text { de los muertos" }\end{array}$ & MIK & mik[aailhuitoontli] \\
\hline & $\begin{array}{l}\text { Tlaxôchimâko "se dan } \\
\text { flores" }\end{array}$ & XOCHI & [tla]xoch[imako] \\
\hline \multirow{3}{*}{ IO } & $\begin{array}{l}\text { Weimikâilwitl "gran fiesta } \\
\text { de los muertos" }\end{array}$ & MIK? & $\begin{array}{l}\text { [wei] mik[ailhuitl] La partícula WEI } \\
\text { se indica con el tamańo mayor del signo }\end{array}$ \\
\hline & $\begin{array}{l}\text { Weimikâilwitl "gran fiesta } \\
\text { de los muertos" }\end{array}$ & MIK & $\begin{array}{l}\text { [wei] mik[aailhuitl] La partícula WEI } \\
\text { se indica con el tamaño mayor del signo }\end{array}$ \\
\hline & $\begin{array}{c}\text { Xokotlwetsi "cae el fruto" } \\
{[\dot{?} ?]}\end{array}$ & \multicolumn{2}{|c|}{ *No es glifo con valor fonético, es un ícono. } \\
\hline
\end{tabular}

II Ochpânistli "barrimiento"

$\mathrm{OCH}$

och[panistli] 
DOI: http://dx.doi.org/10.22201/iie.18703062e.2018.113.2653

\begin{tabular}{ccc}
\hline Casos & Ubicación & Apariciones \\
Registrados & En fuentes & \\
\hline
\end{tabular}

5

Rueda 4 de Veytia*, Duran(333r), Rueda 5 de

en ocasiones el glifo TEKw aparece asociada a la imagen, como el tocado del señor

7: 5 signos y 2 sgnos iconizados

I

5 signos iconizados

5: 3 signos y 2 signos iconizados

I
Borbónico(27), Tudela(17r), Magliabechiano(35r), Ixtlilxochitl(97r), Tovar(VII), Rueda de Boban.
Duran(333v), Telleriano Remensis(Iv), Vaticano $\mathrm{A}(46 \mathrm{r}, 87 \mathrm{r}$ y 87v), Ruedas 4 y 5 de Veytia.

Rueda 4 de Veytia, Duran(335r), Rueda de Boban,Telleriano Remensis(2r)* Vaticano

$$
\mathrm{A}(46 \mathrm{v} \text { y } 87 \mathrm{v})^{*}
$$

Rueda 5 de Veytia

Borbónico(28) Tudela*(I9r), Magliabechiano(37r), Ixtlilxochitl(983), Tovar(VIII).

Rueda 4 de Veytia, Duran(335r), Rueda de Boban,Telleriano Remensis(2r) Vaticano A(46v).

Rueda 5 de Veytia 7

Durán. Otros documentos sólo muestran el palo erguido.

Tovar (IX), Borbónico(30), Tudela(2Ir), Magliabechiano(39r), Ixtlilxochitl(99r),

I5: 4 signos y 8 signos iconizados Telleriano R(3r), Vaticano A(48v), Primeros Memoriales(25Iv), Duran(337r), Mendoza(47r), I5 Matricula de Tributos, (lam25), Rueda de Boban, Ruedas 4 y 5 de Veytia, Humboldt I 
DOI: http://dx.doi.org/10.22201/iie.18703062e.2018.113.2653

I92

\begin{tabular}{|c|c|c|c|}
\hline No. & Ilwitl & Transliteración & Transcripción \\
\hline \multirow[t]{3}{*}{$\mathrm{I} 2$} & $\begin{array}{l}\text { Pachtôntli "pequeña fiesta } \\
\text { del pachtli [heno]" }\end{array}$ & $\mathrm{PACH}$ & pach[tontli] \\
\hline & Teôtleko "sube el Teôtl" & $\begin{array}{l}\text { TE (las huellas que } \\
\text { ascienden) }\end{array}$ & te[otleco] \\
\hline & Teôtleko "sube el Teôtl" & te- E- ko & te[otl]eco \\
\hline \multirow{3}{*}{$\mathrm{I} 3$} & $\begin{array}{l}\text { Weipachtli "gran fiesta del } \\
\text { pachtli [heno]" }\end{array}$ & [WEI] PACH & wei pachtli \\
\hline & $\begin{array}{c}\text { Tepêilwitl "fiesta de los } \\
\text { cerros" }\end{array}$ & TEPE & tepe[eilwitl] \\
\hline & $\begin{array}{l}\text { Tepêilwitl "fiesta de } \\
\text { los cerros" }\end{array}$ & $\begin{array}{l}\text { TEPE (aquí } \\
\text { en contexto } \\
\text { iconográfico) }\end{array}$ & tepe[eilwitl] \\
\hline \multirow[t]{2}{*}{$\mathrm{I} 4$} & $\begin{array}{c}\text { Kechôlli “espátula rosa } \\
\text { [ave similar al flamingo]" }\end{array}$ & KECH-OL & kech[o]olli \\
\hline & $\begin{array}{c}\text { Kechôlli “espátula rosa } \\
\text { [ave similar al flamingo]" }\end{array}$ & \multicolumn{2}{|c|}{$\begin{array}{l}\text { En algunos documentos aparece el dios Mixcoatl ataviado con } \\
\text { varios atributos, ente los que destacan este haz de flechas; por lo } \\
\text { que este puede identificarse como un atributo de la fiesta, aunque al } \\
\text { parecer este no es un signo fonético sino un atributo iconográfico. }\end{array}$} \\
\hline
\end{tabular}

Pânketsalistli

I5 "levantamiento de banderas"

PAN pan[ketsalisli]
Âtemôstli
"descendimiento de agua"
a-te-TEMO
a[a]temo[stli]
Âtemôstli
I6 "descendimiento de agua"
?
variaciones iconográficas del mismo
Âtemôstli
"descendimiento de agua"
variaciones iconográficas del mismo concepto: agua que desciende como lluvia 
DOI: http://dx.doi.org/10.22201/iie.18703062e.2018.113.2653

\begin{tabular}{|c|c|c|}
\hline $\begin{array}{c}\text { Casos } \\
\text { Registrados }\end{array}$ & $\begin{array}{l}\text { Ubicación } \\
\text { En fuentes }\end{array}$ & Apariciones \\
\hline \multirow[b]{2}{*}{ 2: I signo, I iconizado } & $\begin{array}{c}\text { Rueda } 5 \text { de Veytia, Durán(338r), Rueda } 4 \text { de } \\
\text { Veytia. }\end{array}$ & \multirow{3}{*}{6} \\
\hline & Tovar $(\mathrm{X})$ y Telleriano $\mathrm{R}(3 \mathrm{v})$. & \\
\hline I & $\begin{array}{l}\text { Rueda Boban. En la glosa alfabética se } \\
\text { identifica como "Pachtontli" }\end{array}$ & \\
\hline 3 & $\begin{array}{l}\text { Rueda } 4 \text { de Veytia, Durán(338r), Rueda } 5 \text { de } \\
\text { Veytia. }\end{array}$ & \multirow{3}{*}{ I3 } \\
\hline 7 & $\begin{array}{c}\text { Primeros Memoriales (252r), Borbónico(32), } \\
\text { Tudela(23r), Magliabechiano(4Ir), } \\
\text { Ixtlilxochitl(Ioor)*, Tovar(XI). En el Vaticano } \\
\text { A,87r aparece el signo como el rostro de un } \\
\text { G42dios }\end{array}$ & \\
\hline 3 & $\begin{array}{c}\text { Vaticano A(47v), Telleriano R. (4r), Borbónico } \\
\text { (32), Rueda de Boban* }\end{array}$ & \\
\hline \multirow[t]{2}{*}{$\begin{array}{l}\text { 3. sólo en la Rueda de Boban se } \\
\text { incluye el fonograma "ol" }\end{array}$} & $\begin{array}{l}\text { Rueda de Boban, Rueda } 5 \text { de Veytia, Rueda } 4 \\
\text { de Veytia. }\end{array}$ & \multirow[t]{2}{*}{4} \\
\hline & $\begin{array}{c}\text { Códice Vaticano A (87r) y Borbónico }(33) \text {. } \\
\text { Aquí aparecen los dardos y los tocados con } \\
\text { plumones como elementos excentos, de ahí su } \\
\text { importancia. }\end{array}$ & \\
\hline $\begin{array}{l}\text { I3: } 8 \text { signos y } 5 \text { signos en contexto } \\
\text { iconográfico }\end{array}$ & $\begin{array}{l}\text { Rueda } 4 \text { de Veytia, Rueda } 5 \text { de Veytia, Vaticano } \\
\text { A(49v y 87r)Telleriano R(5r), Durán(340v), } \\
\text { Tovar(XII) Humboldt I Borbónico(34), } \\
\text { Tudela(25r), Magliabechiano(43r), Primeros } \\
\text { Memoriales(252r), rueda de Cuilapan. }\end{array}$ & I3 \\
\hline
\end{tabular}

4

3 signos iconizados

5 signos iconizados
Rueda de Boban, Ruedas 4 y 5 de Veytia Vaticano A(87r).

Telleriano R(5v), Durán(42r), Vaticano A(45r). I2

\section{Memoriales(252v), Magliabechiano(44r),}

Tovar (XII), Tudela(26r), Primeros Ixtlilxochitl(Iorv). 
DOI: http://dx.doi.org/10.22201/iie.18703062e.2018.113.2653

I94

\begin{tabular}{|c|c|c|c|}
\hline No. & Ilwitl & Transliteración & Transcripción \\
\hline
\end{tabular}

I7 Tititl "estiramiento"

Iskalli sin traducción clara.

En distintas fuentes se traduce como: 'reavivar', 'resucitar', 'adiestrar', 'crecer'

I8

Iskalli

KAL [is]kalli (los tres documentos que presentan lectura glífica incorporan diferentes signos fonéticos como complemento a la "casa")

No es glifo con valor fonético, es un ícono.

Iskalli

neemontemi

No hay representación sistemática, no se representan con glifos.

Véase notas de la tabla 4. 
DOI: http://dx.doi.org/10.22201/iie.18703062e.2018.113.2653

\begin{tabular}{|c|c|c|}
\hline $\begin{array}{l}\text { Casos } \\
\text { Registrados }\end{array}$ & $\begin{array}{l}\text { Ubicación } \\
\text { En fuentes }\end{array}$ & Apariciones \\
\hline \multirow[t]{2}{*}{$\begin{array}{l}\text { 5 imágenes que hacen alusión a } \\
\text { “jalar” o "estirar”, pero no se puede } \\
\text { reconstruir la lectura. }\end{array}$} & $\begin{array}{c}\text { Durán(432v), Rueda de Veytia 5, Tovar(XIII), } \\
\text { Rueda de Veytia 5, Rueda de Boban. En } \\
\text { el Vaticano A(87r) aparece Xiuhtecuhtli. } \\
\text { En el resto de los documentos aparece } \\
\text { la diosa Cihuacoatl como atributo de la } \\
\text { veintena:Tudela(27r), Borbónico(36), } \\
\text { Magliabechiano(45r), Ixtlilxochitl(IO2r), } \\
\text { Telleriano R(6r), Vaticano A(45v), P. } \\
\text { Memoriales(253r), }\end{array}$ & \multirow[t]{2}{*}{--} \\
\hline & $\begin{array}{c}\text { Rueda de Veytia 4, Rueda de Boban, } \\
\text { Tovar(XIII) }\end{array}$ & \\
\hline 2 & Durán(2Iv), Rueda de Veytias, & 8 \\
\hline 3 & $\begin{array}{c}\text { El resto de los documentos presentan al dios } \\
\text { del fuego, Xiuhtecuhtli: Vaticano A }(87 \mathbf{r}) \text {, } \\
\text { Borbónico, Tudela }\end{array}$ & \\
\hline
\end{tabular}

